\title{
Northern Tosk Albanian
}

Stefano Coretta ${ }^{1,2}$, Josiane Riverin-Coutlée ${ }^{2}$, Enkeleida Kapia $^{2,3}$, and Stephen Nichols ${ }^{4,5}$

${ }^{1}$ Linguistics and English Language, University of Edinburgh

${ }^{2}$ Institute of Phonetics and Speech Processing, Ludwig-Maximilians-Universität München

${ }^{3}$ Academy of Albanological Sciences

${ }^{4}$ Linguistics, Philology and Phonetics, University of Oxford

${ }^{5}$ Language and Linguistics, University of Essex

\section{June 2022}

\section{Introduction}

Albanian (endonym: Shqip; Glotto: alba1268) is an Indo-European language which has been suggested to form an independent branch of the Indo-European family since the middle of the nineteenth century (Bopp 1855; Pedersen 1897; Çabej 1976). Though the origin of the language has been debated, the prevailing opinion in the literature is that it is a descendant of Illyrian (Hetzer 1995). Albanian is currently spoken by around 6-7 million people (Rusakov 2017; Klein et al. 2018), the majority of whom live in Albania and Kosovo, with others in Italy, Greece, North Macedonia and Montenegro. Figure 1 shows a map of the main Albanian-speaking areas of Europe, with major linguistic subdivisions according to Gjinari (1988) and Elsie \& Gross (2009) marked by different colours and shades. 


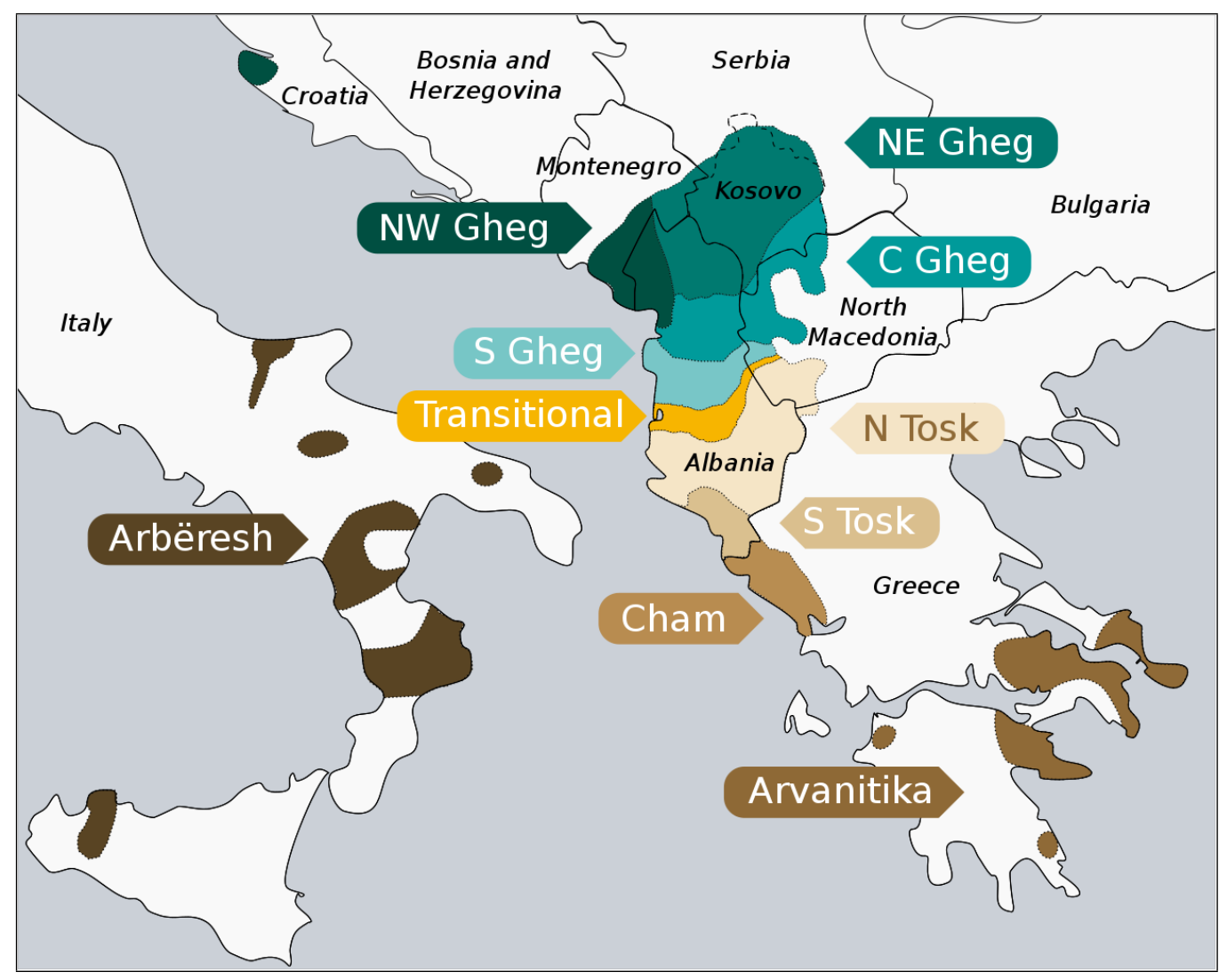

Figure 1: Map of the Albanian-speaking areas of Europe. Subdivisions are based on Gjinari (1988) and Elsie \& Gross (2009). CC-BY-SA 4.0 Stefano Coretta, Júlio Reis. 
At the macro-level, Albanian includes two main varieties: Gheg, spoken in Northern Albania, Kosovo and parts of Montenegro and North Macedonia; and Tosk, spoken in Southern Albania and in parts of Greece and Southern Italy (von Hahn 1853; Desnickaja 1976; Demiraj 1986; Gjinari 1985; Beci 2002; Shkurtaj 2012; Gjinari et al. 2007). At the meso-level, Gheg and Tosk are usually further divided into the following sub-varieties (Gjinari 1988): Gheg includes Northwestern Gheg, Northeastern Gheg, Central Gheg and Southern Gheg; while Tosk includes Northern Tosk, Southern Tosk, Cham, Arvanitika and Arbëresh. The speakers recorded for this illustration were all born and raised in areas where Northern Tosk is spoken, namely the counties of Përmet and Fier. Thus, we consider the doculect (Cysouw \& Good 2013) discussed here to belong to Northern Tosk.

Northern Tosk differs from other Tosk and Gheg varieties on several phonological and phonetic features. For instance, Gheg has contrastive vowel nasalisation, while Tosk lacks it, e.g. 'drink.IMP:2SG' and 'numb.IMP:2SG' are realised as /pi/ vs /pĩ/ in Gheg but as /pi/ vs /mpi/ in Tosk (Beci 1995). Northern Tosk also lacks vowel length contrasts, whereas pockets of Southern Tosk, Southern Gheg, Central Gheg and Northeastern Gheg contrast long and short vowels and Northwestern Gheg contrasts short, long and extra-long vowels (e.g. Beci 1995; Çabej 1975; Gjinari et al. 2007; Shkurtaj 1975).

The five consultant speakers ( 2 females and 3 males) were aged between 25 and 33 years old. They were digitally recorded $(44,100 \mathrm{~Hz}, 16$ bits) in an anechoic chamber at the Institute of Phonetics and Speech Processing at the Ludwig-Maximilians-Universität München (Germany) using a Neumann TLM 103 microphone connected to a Steinberg UR824 console, while reading a word list, a list of sentences and The North Wind and the Sun story. Two of the speakers were visiting family when recorded and still lived in Albania whereas the remaining three lived in Munich but reported speaking Northern Tosk with a member of their household on a daily basis. The participants were first screened by one of the authors (EK), who is a native speaker of Northern Tosk, to make sure they 
Table 1: Phonemic consonants of Northern Tosk Albanian.

\begin{tabular}{|c|c|c|c|c|c|c|c|c|c|c|c|c|c|c|c|}
\hline \multirow{3}{*}{ Plosive } & \multirow{2}{*}{\multicolumn{2}{|c|}{ Bilabial }} & \multirow[t]{2}{*}{ Labiodental } & \multicolumn{2}{|c|}{ Dental } & \multirow{2}{*}{\multicolumn{2}{|c|}{ Alveolar }} & \multicolumn{3}{|c|}{ Postalveolar } & \multirow[t]{4}{*}{ Retroflex } & \multirow[t]{4}{*}{ Palatal } & \multirow{2}{*}{\multicolumn{2}{|c|}{ Velar }} & \multirow[t]{2}{*}{ Glottal } \\
\hline & & & & Plain & Velarised & & & Apical & & ninal & & & & & \\
\hline & $\mathrm{p}$ & $\mathrm{b}$ & & & & $\mathrm{t}$ & $\mathrm{d}$ & & & & & & & $\mathrm{g}$ & \\
\hline Affricate & & & & & & ts & $\mathrm{dz}$ & $\mathrm{t} \int \mathrm{d} 3$ & $\mathrm{t} \int_{0}$ & $\mathrm{~d} 3$ & & & & & \\
\hline Nasal & & $\mathrm{m}$ & & & & & $\mathrm{n}$ & & & & & $\mathrm{n}$ & & & \\
\hline Trill & & & & & & & $\mathrm{r}$ & & & & & & & & \\
\hline Flap & & & & & & & & & & & $\mathrm{r}$ & & & & \\
\hline Fricative & & & f $\quad$ v & $\theta \quad \partial$ & & $\mathrm{s}$ & $\mathrm{z}$ & & $\int$ & 3 & & & & & $\mathrm{~h}$ \\
\hline Approximant & & & & & & & & & & & & $\mathrm{j}$ & & & \\
\hline Lateral approximant & & & & & $1^{\mathrm{Y}}$ & & 1 & & & & & & & & \\
\hline
\end{tabular}

were representative speakers of the variety. Immediately prior to the recordings, each speaker also engaged in a 10-minute conversation with this author to reduce possible effects from German or English (Antoniou et al. 2010). ${ }^{1}$ For a full report of the methods employed in this study, the reader is referred to the online supplementary materials.

Following recommendations for Open Science in Crüwell et al. (2019) and Berez-Kroeker et al. (2018), data and code used to produce the analyses discussed in this paper are available on the Open Science Framework at https://osf.io/vry3h/ (Coretta et al. 2021). 


\section{Consonants}

\begin{tabular}{|c|c|c|c|c|c|c|}
\hline /pata/ & pata & 'duck' & $\mathrm{r}$ & /rapi/ & rrapi & 'oak tree' \\
\hline /bari/ & bari & 'grass' & $\mathrm{r}$ & $/ \mathrm{ra}_{3} /$ & rashë & 'I fell' \\
\hline /tapa/ & tapa & 'cork' & $\mathrm{f}$ & /fati/ & fati & 'luck' \\
\hline /data/ & data & 'date' & $\mathrm{v}$ & /vata/ & vata & 'epaulette' \\
\hline /kati/ & kati & 'floor' & $\theta$ & /Өat3/ & thatë & ‘dry’ \\
\hline /gati/ & gati & 'ready' & ð & /ðat3/ & dhatë & 'you gave' \\
\hline /tsitsa/ & cica & 'boobs' & s & $/ \mathrm{sal}^{\mathrm{V} a} /$ & salla & 'big room, hall' \\
\hline /dzidza/ & xixa & 'sparkles' & $\mathrm{z}$ & $/ \mathrm{zal}^{\mathrm{x}} \mathrm{i} /$ & zalli & 'pebbles' \\
\hline /t〕aji/ & çaji & 'tea' & $\int$ & /Sava/ & shava & 'I scolded' \\
\hline /dzaja/ & xhaja & 'uncle' & 3 & /3aba/ & zhaba & 'lizard' \\
\hline /țava/ & qava & 'I cried' & $\mathrm{h}$ & /han3/ & hanë & 'they eat' \\
\hline /dzakaku/ & gjaku & 'blood' & $\mathrm{j}$ & /jan3/ & janë & 'they are' \\
\hline /mana/ & mana & 'mulberries' & 1 & /lava/ & lava & 'I washed' \\
\hline /nana/ & (nina-)nana & 'lullaby'2 & $1^{\mathrm{Y}}$ & /lyava/ & llava & 'lava' \\
\hline /nerka/ & njerka & 'stepmother' & & & & \\
\hline
\end{tabular}

The 29 phonemic consonants of Northern Tosk described here are shown in Table 1. For each consonant, our description is based on the consonant that occurs as the first segment of near-minimal pairs consisting of trochaic words. The illustrative words are taken from Beci (2004), with these exceptions: bari, xhaja, mana, nana, njerka, fati, vata, lava and llava. Northern Tosk contrasts eight manners of articulation (as defined in International Phonetic Association 1999): plosive, affricate, nasal, trill, flap, fricative, approximant and lateral approximant. In total, there are nine contrastive places of articulation: labial, labiodental, dental, alveolar, postalveolar, retroflex, palatal, velar and glottal. The postalveolar place of articulation further contrasts apical and laminal articulators in the affricates. Plosives, affricates and fricatives (with the exception of

\footnotetext{
${ }^{1}$ Participants completed an online informed consent form and a basic sociolinguistic questionnaire. PDF versions of these Google Forms can be found in the forms/ folder at https://osf.io/u43sg/. The recording sessions took place between February and March 2020.

${ }^{2}$ Here nana constitutes the second half of the reduplicated form nina-nana 'lullaby'.
} 


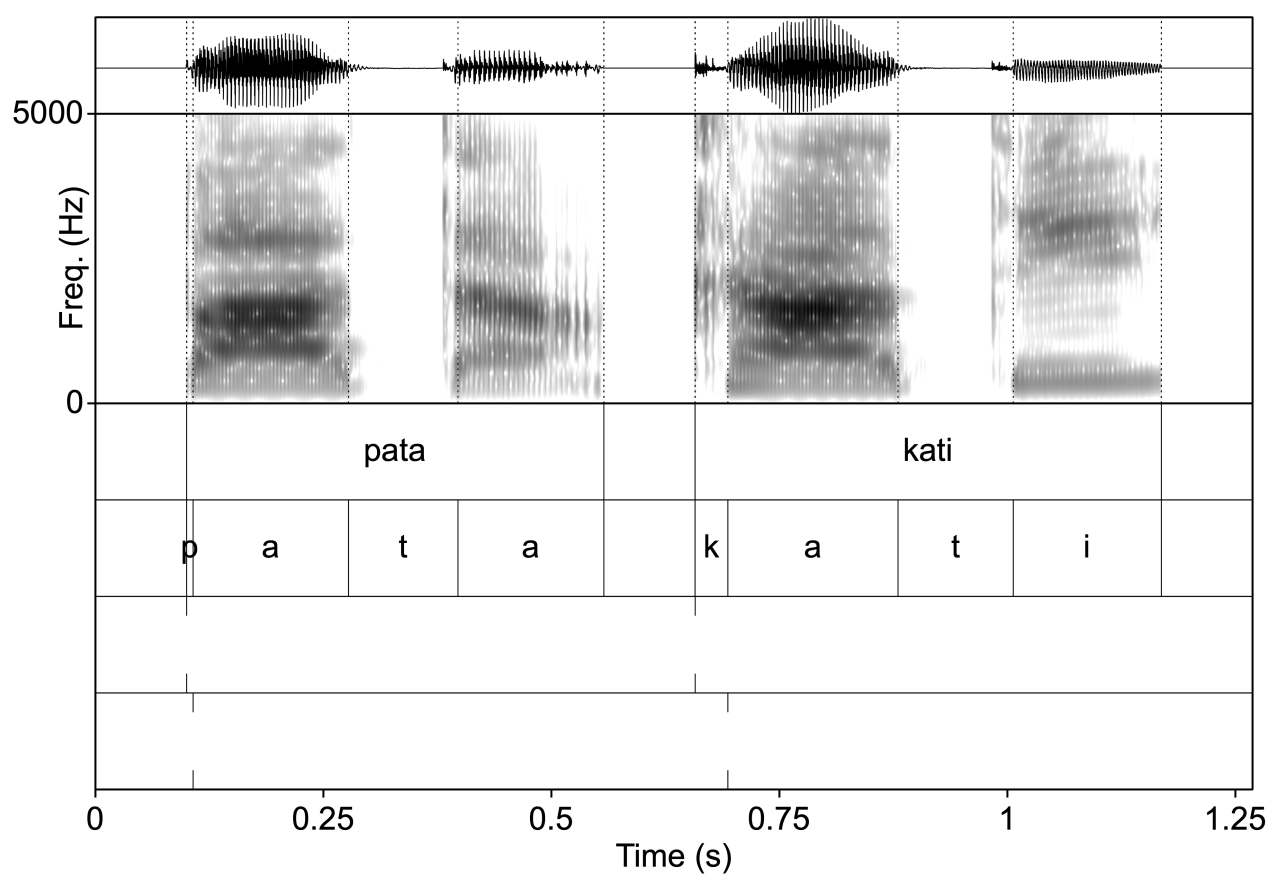

Figure 2: Segmentation of release and voice onset in /pata/ 'duck' and /kati/ 'floor', uttered by S04. Tiers from top to bottom: word, segments, $\mathrm{C} 1$ release, voice onset. (The left boundary of word-initial voiceless stops has been placed at the time of release, since the location of closure onset cannot be seen from the spectrogram.)

/h/) contrast voiceless and voiced phonemes.

Plosives Northern Tosk possesses six plosives: bilabial /p b/, (apico-)alveolar $/ \mathrm{t} \mathrm{d} /$ and velar $/ \mathrm{k} \mathrm{g} /$. Figure 2 shows an example of the segmentation of stop release and voice onset in pata and kati. Figure 3 shows raw VOT values obtained for the initial plosive of the words pata, bari, tapa, data, kati and gati as produced by the five speakers. Each speaker repeated each word three times, so that there are three points per speaker/consonant in the figure. The voiceless plosives $/ \mathrm{p} \mathrm{t} \mathrm{k/} \mathrm{have} \mathrm{a} \mathrm{pos-}$ itive VOT, with / k/ being more post-aspirated (and more so for S05 than other speakers). The mean VOT of /p/ is $14 \mathrm{~ms}(\mathrm{SD}=6), / \mathrm{t} / 15 \mathrm{~ms}(10)$, /k/ $55 \mathrm{~ms}$ (26). The voiced plosives / $\mathrm{d} \mathrm{d} \mathrm{g/} \mathrm{have} \mathrm{robust} \mathrm{vocal} \mathrm{fold} \mathrm{vi-}$ 
Table 2: Mean VOT and standard deviation of word-initial plosive (15 tokens per word).

\begin{tabular}{llllll}
\hline word & mean $(\mathrm{ms})$ & sd & word & mean $(\mathrm{ms})$ & sd \\
\hline pata & 14 & 6 & bari & -108 & 27 \\
tapa & 15 & 10 & data & -117 & 19 \\
kati & 55 & 26 & gati & -106 & 23 \\
\hline
\end{tabular}

bration during their closure (i.e. pre-voicing or negative VOT). Their VOT values tend to show more intra- and inter-speaker variability than those of the voiceless plosives. The mean VOT values are similar across these consonants and they show greater standard deviations than the voiceless plosives: /b/ -108 ms (SD = 26), /d/ -117 ms (19), /g/ -106 ms (26).

FRICATIVES Northern Tosk has nine fricatives at the labiodental, dental, alveolar, postalveolar and glottal places of articulation. In all places but glottal, a voiceless fricative contrasts with its voiced counterpart. The fricatives /f v/ are labiodental, / $\theta$ ठ/ (inter-)dental, /s z/ (apico-)alveolar, $/ \int 3 /$ (lamino-)postalveolar and $/ \mathrm{h} /$ (voiceless) glottal.

The left-hand panels of Figure 4 show the spectral centre of gravity (CoG) of voiceless (top) and voiced fricatives (bottom). As is seen crosslinguistically, /s z/ are well separated from $/ \int 3 /$ in having a markedly higher CoG than the latter (see for example Maniwa et al. 2009 and references therein). Notably, the labiodental and dental fricatives are not distinguished by CoG. This is not surprising in light of the common sound change from dental to labiodental fricatives, as seen in varieties of English like Northern British English (Baranowski \& Turton 2015). The power spectrum slices in Figure 5 show the contrast between $/ \mathrm{f} \theta /$ and $/ \mathrm{J} /$ : although these fricatives have similar CoG, the fricatives $/ \mathrm{f} \theta /$ have a more diffuse spectrum than $/ \mathrm{S} /$.

In the isolated words from the word list, the voicing contrast is consistent and robust for all speakers: the voiceless fricatives show no passive voicing from neighbouring segments and the voiced fricatives are usually 


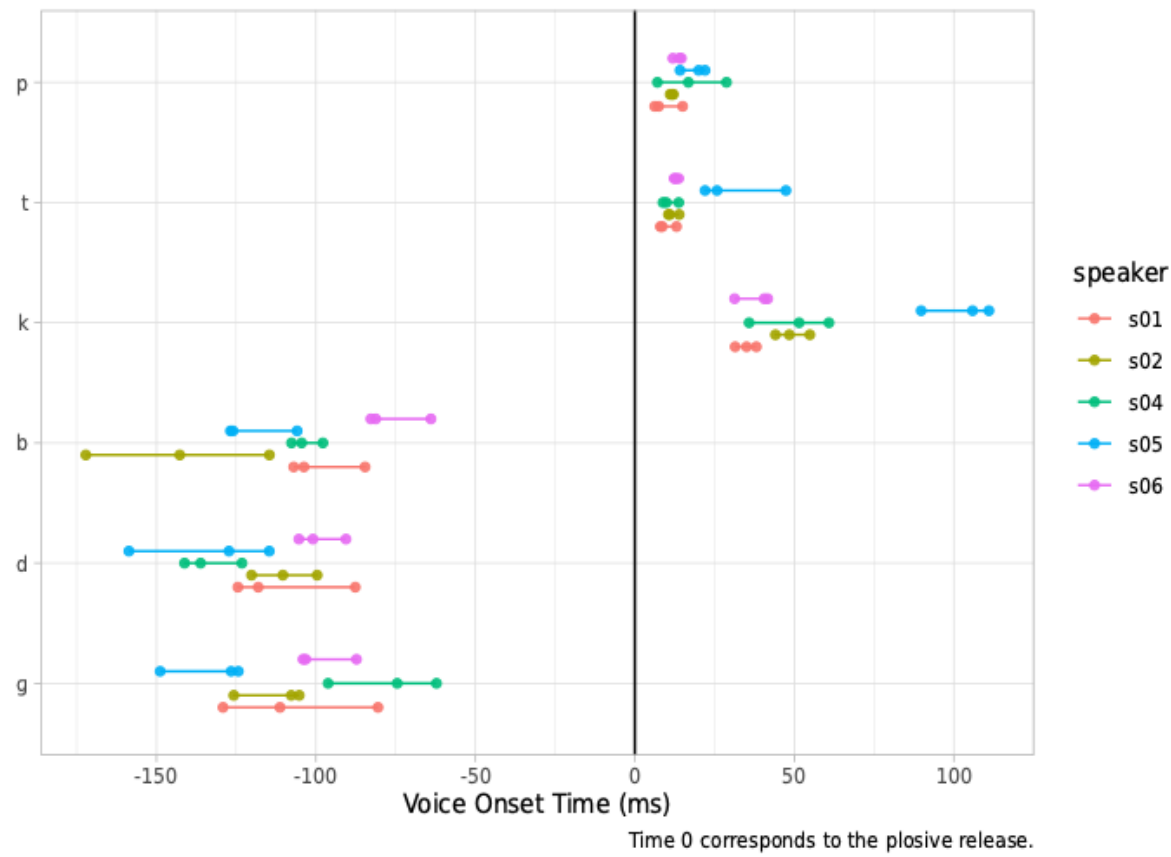

Figure 3: Voice-onset time (VOT) of voiceless and voiced plosives as measured in the first consonant of pata, bari, tapa, data, kati and gati. VOT $=0$ corresponds to the time of consonant release. Each speaker repeated each word three times (each repetition is represented by a dot in the figure). 


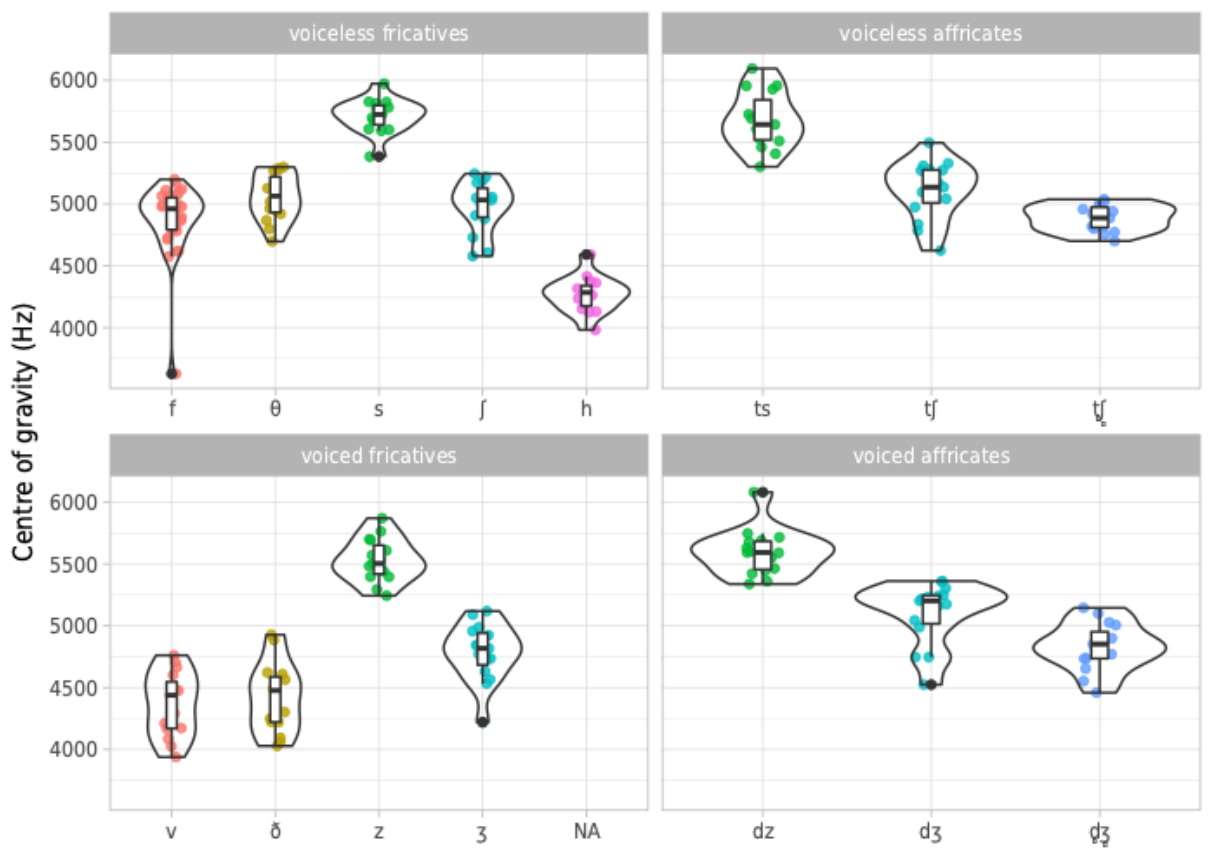

Figure 4: Spectral centre of gravity of fricatives and affricates. The violins show the probability density function of the CoG, while the superimposed box-plots indicate the median (solid horizontal line), the interquartile range (IQR; box) and the value corresponding to \pm 1.5 IQR from the first and third quartile (whiskers). The individual observations are represented by points, jittered horizontally to reduce overlap. 


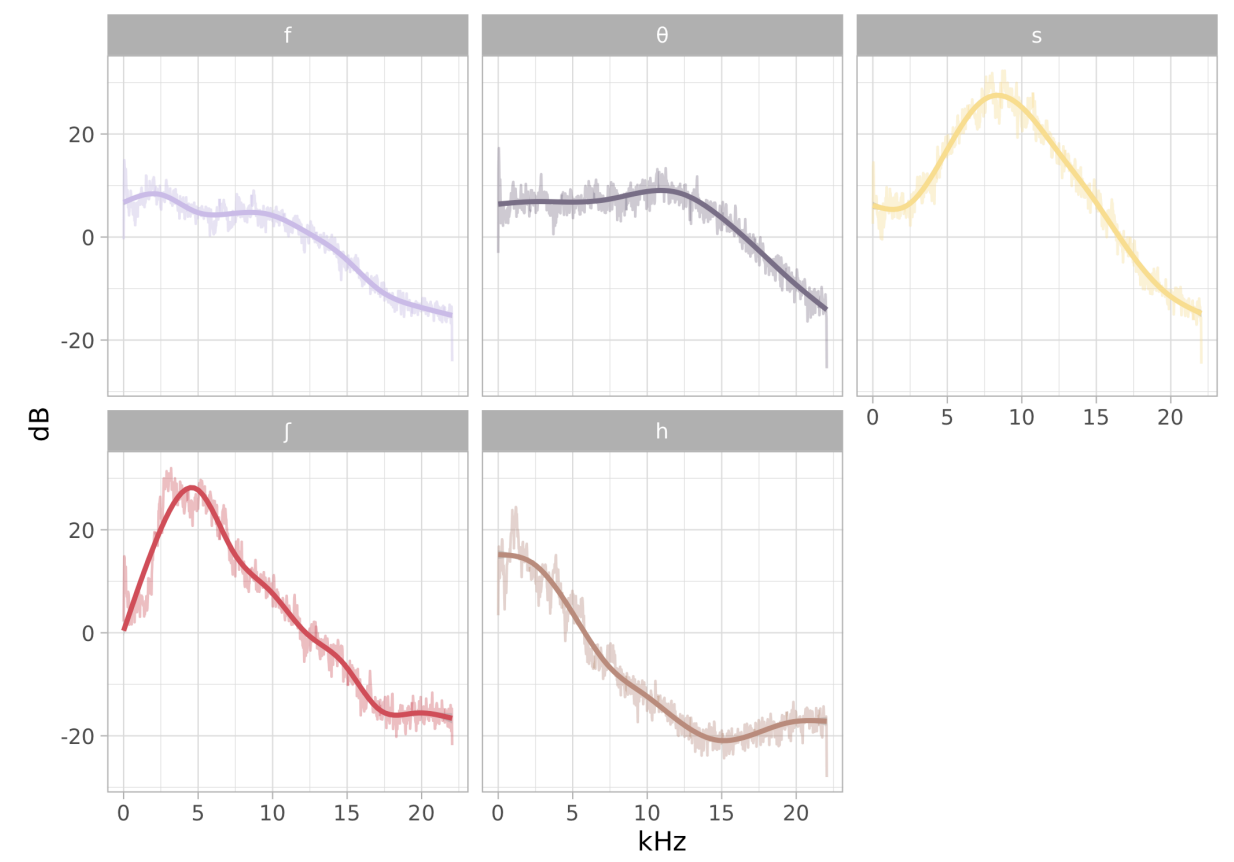

Figure 5: Mean power spectrum slices of the voiceless fricatives. The mean raw spectrum slices (lines with lighter hue) were calculated for each fricative based on all the repetitions of the words illustrating fricatives, from all the speakers. GAM smoothed spectra (thicker lines with darker hues) are superimposed to the mean raw spectra. 


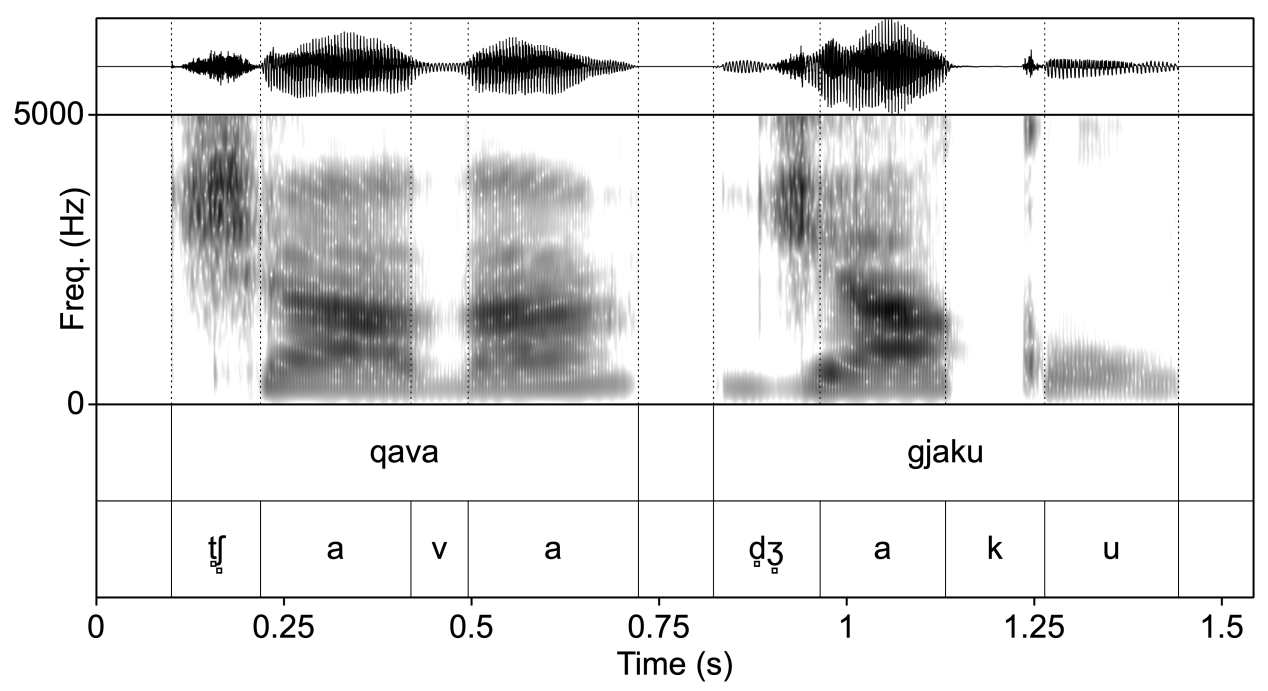

Figure 6: Waveforms and spectrograms of qava 'cried' and giaku 'blood' as produced by speaker S04.

produced with vocal fold vibration throughout the entire consonant. However, the glottal fricative $/ \mathrm{h} /$ is at times realised as voiced [ $\mathrm{h}$ ] in connected speech, as can been seen in the phonetic transcription of The North Wind

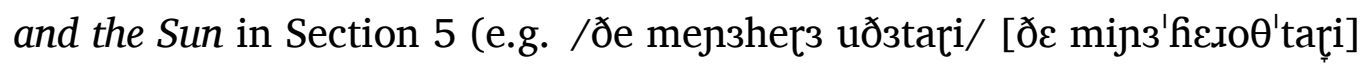
'and immediately the traveller').

AFFRICATES The consonants represented by $\langle q\rangle$ and $\langle g j\rangle$ in writing are traditionally described as plosives (Bevington 1971; Newmark 1957; Newmark et al. 1982; Dodi 1996; Memushaj 2005, 2011; Jubani-Bengu 2011, 2012), though Lowman (1932) classifies them as affricates and Belluscio (2014) reports that they are realised with strong frication. In our data, in fact, they are never realised as plosives and are instead clearly affricated for all speakers. The waveforms and spectrograms of qava 'I cried' and gjaku 'blood' as produced by speaker S04 are provided in Figure 6. From these it can be seen that the plosive closure in word-initial position is followed by a period of frication of substantial duration.

Another contested aspect of these consonants concerns their place of articulation, which is generally reported to be palatal or pre-palatal/alveolo- 
palatal (Lowman 1932; Bevington 1971; Dodi 1996; Kolgjini 2004; Memushaj 2005, 2011; Jubani-Bengu 2011, 2012; Belluscio 2014). On the other hand, Newmark (1957) and Newmark et al. (1982) group $\langle\mathrm{q}\rangle$ and $\langle\mathrm{gj}\rangle$ together with the postalveolar fricatives and affricates $/ \int 3 \mathrm{t} \int \mathrm{d}_{3} /$ under the label "laminal" and observe that the tongue tip is raised during the production of the former. To ascertain the place of articulation of $\langle q\rangle$ and $\langle\mathrm{gj}\rangle$, we carried out a palatographic investigation of various consonants, displayed in Figure 7. Palatograms were produced for the lingual plosive and affricate consonants by applying a mixture of vegetable oil and charcoal powder to the tongue of one of the authors (EK) who then uttered one of the consonants flanked by /a/ (e.g. /ata/). A picture of the impression of the tongue on the hard palate was taken with the help of a mirror (Ladefoged 2003). The black markings on the palate indicate the place of contact with the tongue surface.

The affricates $\langle\mathrm{q}\rangle$ and $\langle\mathrm{gj}\rangle$ (second row from the bottom) are produced with greater tongue contact than the postalveolar affricates $/ \mathrm{t} \int \mathrm{d}_{3} /$ (third row), though the location of the anterior contact is approximately the same. We interpret this as an indication that $\langle\mathrm{q}\rangle$ and $\langle\mathrm{gj}\rangle$ are articulated with a lamino-postalveolar closure (cf. Ladefoged \& Maddieson 1996: 29) while $/ \mathrm{t} \int \mathrm{d} 3 /$ have an apico-postalveolar closure. This is reflected in our choice to use the plain postalveolar symbols $/ \mathrm{t} \int \mathrm{d}_{3} /$ for the apico-postalveolar affricates and the same symbols with the addition of the laminal diacritic $/ \mathrm{t} \int_{\mathrm{a}} \mathrm{d}_{\mathrm{a}} /$ for the lamino-postalveolar affricates $\langle\mathrm{q}\rangle$ and $\langle\mathrm{gj}\rangle$.

The right panels of Figure 4 show the spectral centre of gravity (CoG) of the fricative portion of the voiceless (top) and voiced affricates (bottom). The affricates /ts dz/ have the highest CoG, consistent with /s z/. Figure 7 further shows that the tongue-contact area of the alveolar affricates and that of the alveolar plosives $/ \mathrm{t} d /$ is virtually identical. The apicopostalveolar affricates $/ \mathrm{t} \int \mathrm{d} 3 /$ have CoG values that match those of $/ \int 3 /$. Finally, the lamino-postalveolar $/ \mathrm{t} \int \mathrm{d} z /$ have lower CoGs than the other affricates, consistent with the spectral properties of lamino-postalveolar consonants discussed in Ladefoged \& Maddieson (1996: 30). As for voicing, 

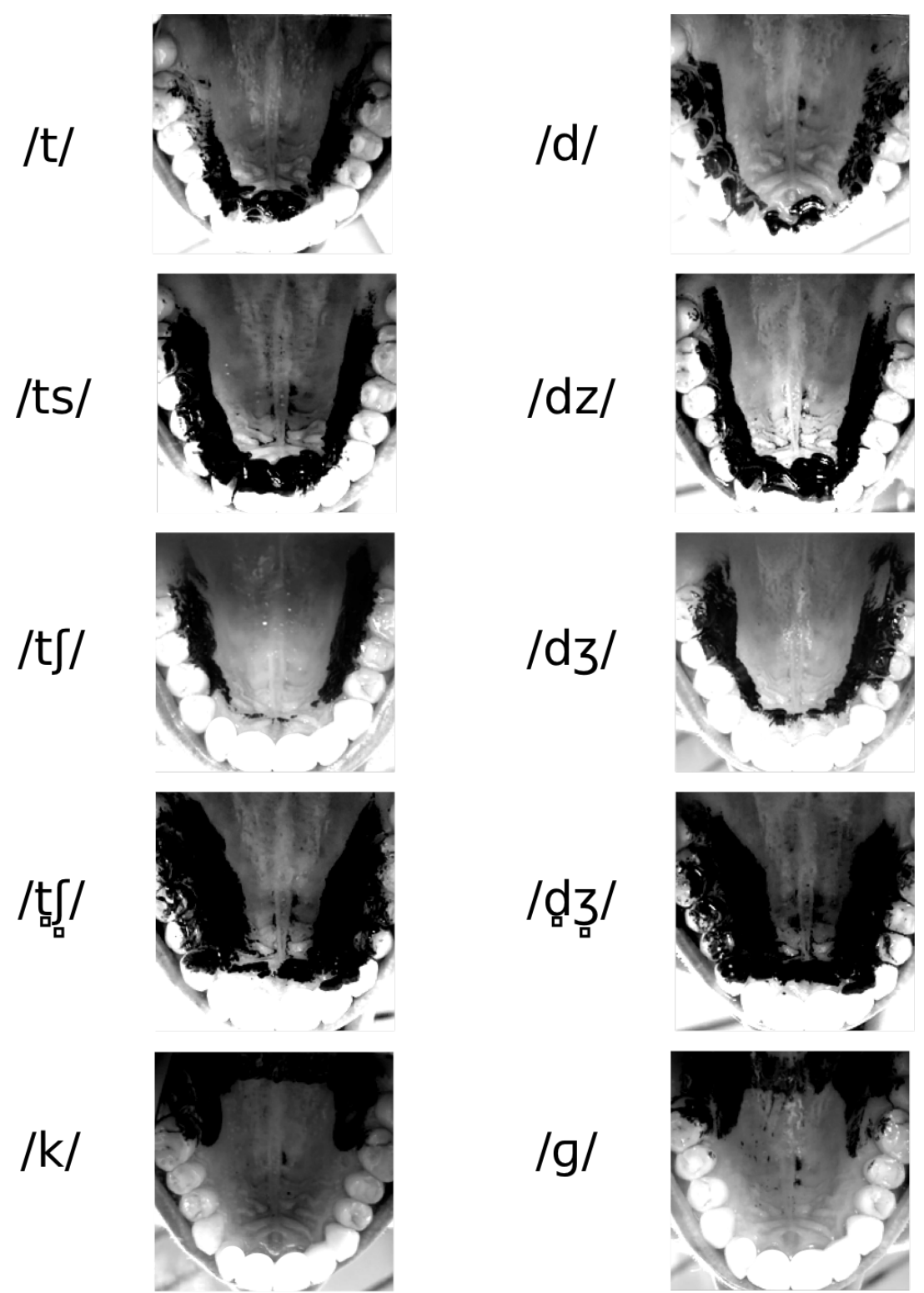

Figure 7: Palatograms of lingual plosives and affricates. The areas in black indicate the area of contact between the tongue and the palate. 


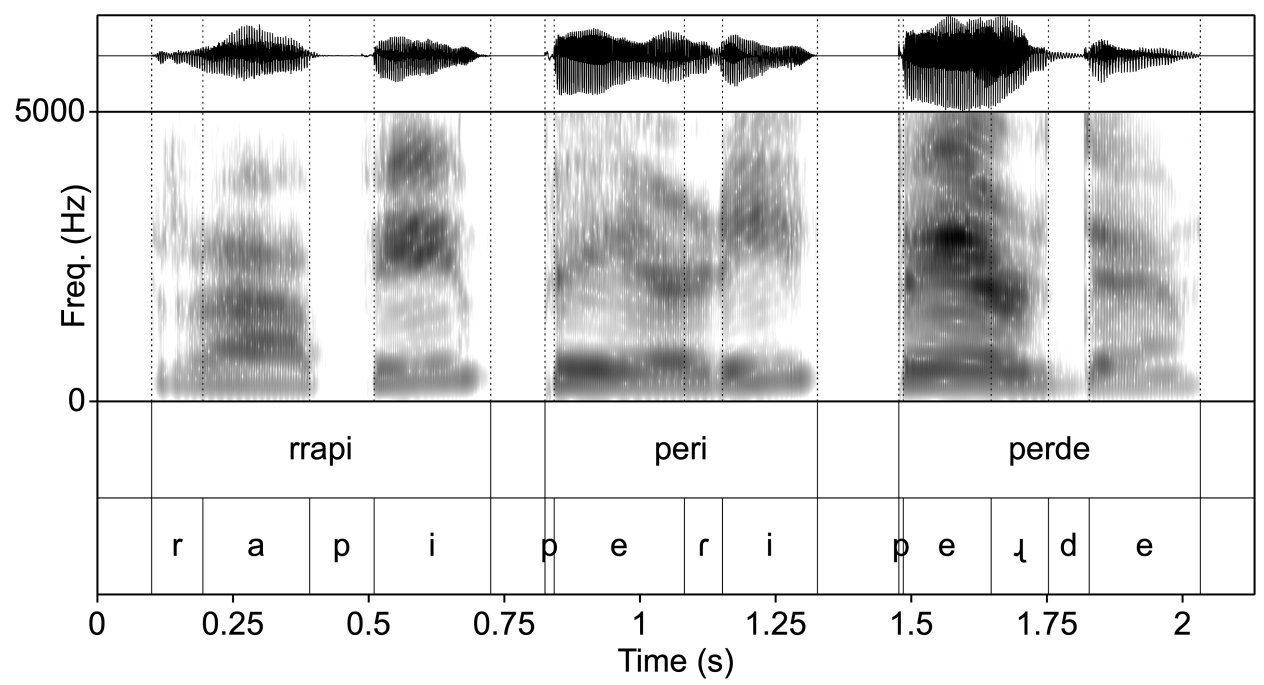

Figure 8: Waveforms and spectrograms of rrapi 'oak tree', peri 'thread' and perde 'curtains' as produced by speaker S04.

the voiceless affricates are produced with no vocal fold vibration, while voiced affricates are produced with fold vibration during both closure and post-release frication. Thus, in total, we identified three voiceless-voiced pairs of affricates: alveolar /ts dz/, apico-postalveolar / $\mathrm{t} \int \mathrm{d} 3 / \mathrm{and}$ laminopostalveolar $/ \mathrm{t} \int_{\mathrm{a}} \mathrm{d} z \mathrm{~g} /$.

RHoтics Northern Tosk contrasts two rhotics, written as $\langle\mathrm{r}\rangle$ and $\langle\mathrm{rr}\rangle$, both of which can occur word initially, medially and finally. While our speakers always realised $\langle\mathrm{rr}\rangle$ as an alveolar trill $[\mathrm{r}],\langle\mathrm{r}\rangle$ was characterised by a great deal of allophonic variation, as also previously noted by Belluscio (2014). Among the range of realisations for $\langle r\rangle$, we found retroflex flaps $[r]$ and retroflex approximants $[\tau]$. These seem to be in complementary distribution, with [ $]$ ] tending to appear in coda position, although for some speakers and in some words, word-initial / $\mathrm{r} /$ was also realised as a retroflex approximant [t]. Impressionistic studies and some case-study analyses suggest that $/ \mathrm{r} /$ may increasingly be realised as $[\tau]$ or variants thereof in different varieties of Albanian (Hysenaj 2009; Jubani-Bengu 2012; Belluscio 2016). Figure 8 shows illustrative examples of the three 
main rhotic allophones. The limited set of contexts in the words collected does not allow us to make definitive generalisations about the distribution of these allophones and future work is warranted on this matter. We have chosen to use $/ \mathrm{r} /$ for $\langle\mathrm{rr}\rangle$ and $/ \mathrm{r} /$ for $\langle\mathrm{r}\rangle$, though as noted above, $/ \mathrm{r} /$ is frequently realised as $[\imath]$.

LATERALS Northern Tosk contrasts two lateral consonants, namely a plain alveolar lateral approximant $/ 1$ and a velarised dental lateral approximant $/ 1^{\mathrm{y}} /$. As evidenced by the palatograms in Figure 9, the tonguetip closure is produced just behind the alveolar process for $/ 1 /$ while it is clearly dental for $/ 1^{\mathrm{y}} /$. Figure 10 shows the smoothed midsagittal tongue contours of $/ 1 /$ and $/ 1^{\mathrm{y}} /$ as gathered from ultrasound tongue imaging, extracted from a single utterance of the nonce words ala and alla respectively. In this figure, the tongue tip is on the right-hand side. The dashed line indicates the surface of the hard palate. The posterior part of the tongue dorsum is raised in $/ 1^{\mathrm{y}} /$, making it velarised. Moreover, the plain lateral /1/ shows some degree of body raising, as can be seen in Figure 10. We take these results from palatography and ultrasound imaging to indicate that $/ 1^{\mathrm{y}} /$ is a velarised (lamino-)dental lateral approximant (Dodi 2004; Belluscio 2014), while $/ 1 /$ is an (apico-)alveolar lateral approximant with some degree of palatalisation.

The velarised lateral $/ 1^{\mathrm{y}} /$ is sometimes vocalised in running speech, as can be observed in the phonetic transcription of The North Wind and the

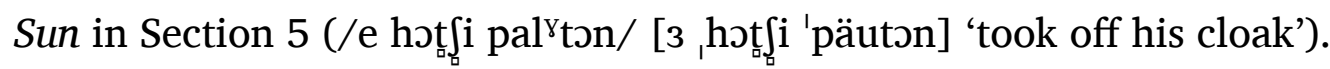

NASALS AND APPROXIMANT Finally, Northern Tosk has three nasal consonants at the bilabial $/ \mathrm{m} /$, alveolar $/ \mathrm{n} /$ and palatal $/ \mathrm{n} /$ places of articulation and one palatal approximant $/ \mathrm{j} /$. We did not identify any peculiarities in these consonants that would set them apart from their canonical realisation as seen cross-linguistically. 

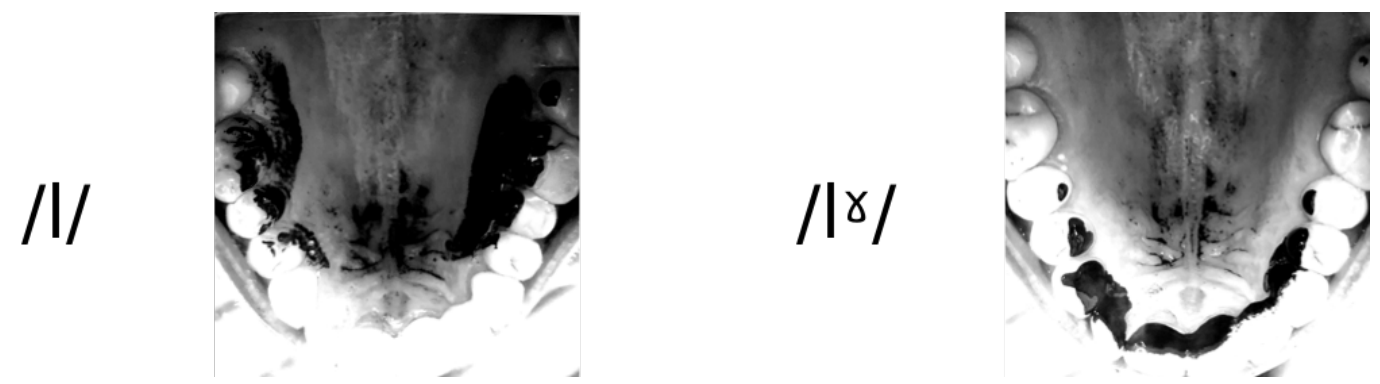

Figure 9: Palatograms of the lateral approximants $/ 1$ and $/ 1 \mathrm{r} /$. Note the fronter (dental) closure in $/ 1^{\mathrm{r}} /$.

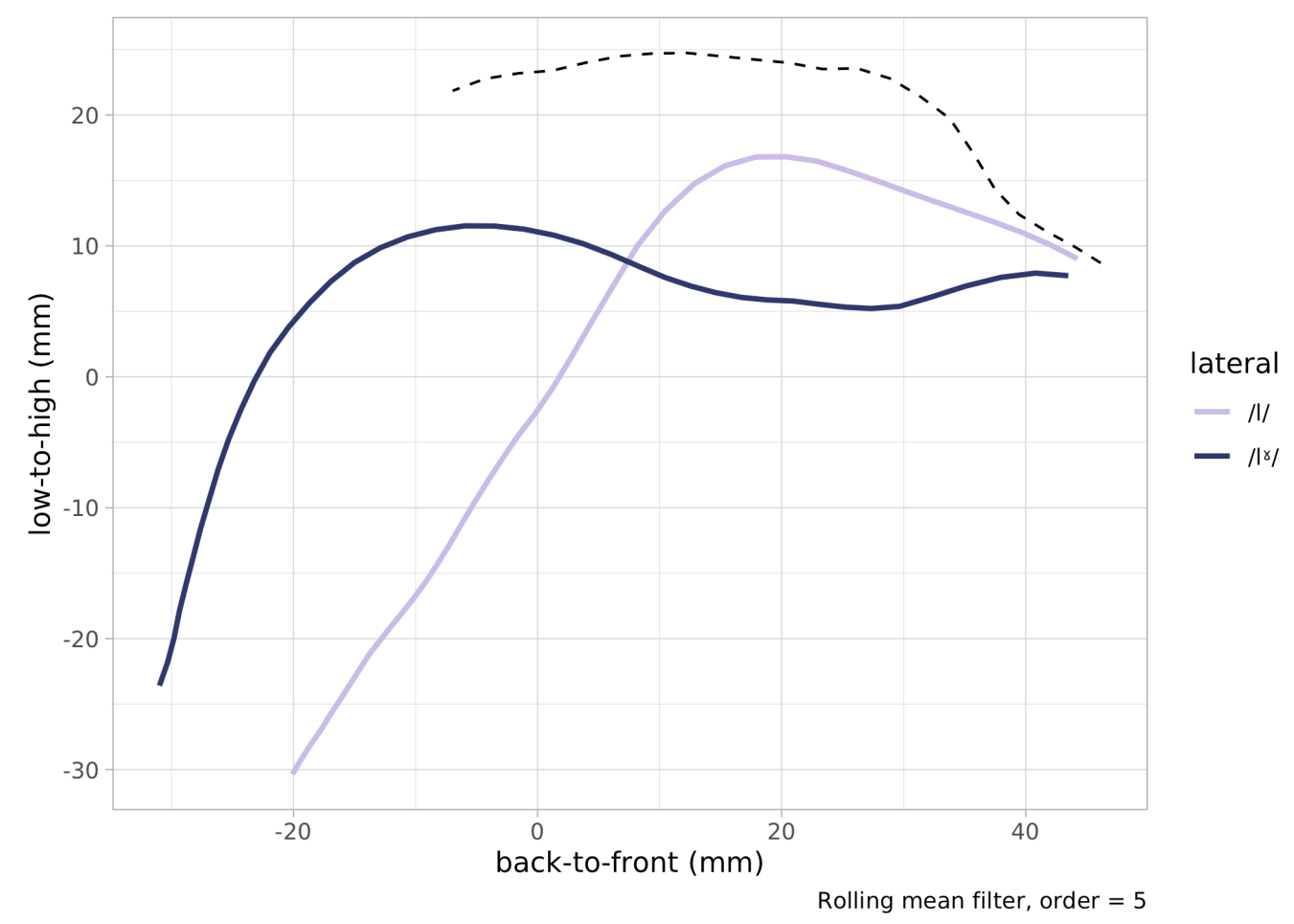

Figure 10: Smoothed midsagittal tongue contours of $/ \mathrm{l} /$ and $/ 1^{\mathrm{y}} /$ from ultrasound tongue imaging of one utterance of $/ \mathrm{ala} / \mathrm{and} / \mathrm{al}{ }^{\mathrm{\gamma}} \mathrm{a} /$. The dashed line marks the surface of the hard palate. The tongue body is somewhat raised in $/ 1 /$, while the dorsum is in $/ 1^{\mathrm{y}} /$. 


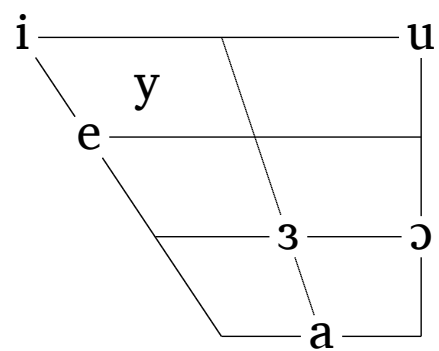

Figure 11: Vowel chart of Northern Tosk. The position of the vowels in the chart approximately reflects their position in the F1/F2 space (see Figure 12). ${ }^{3}$

\section{Vowels}

i /pik3/ pikë 'drop, dot'

y /pyk3/ pykë 'head (of a hammer)'

u /purs/ puro 'cigar'

e /peri/ peri 'thread'

3 /pзr/ për 'for'

ว /por/ por 'but'

a /para/ para 'before'

Northern Tosk has seven vowels: /i y u e 3 o a/. Figure 11 shows a trapezoid with the vocalic symbols placed approximately according to their mean position in the F1/F2 normalised-Hertz space displayed in Figure 12. Hertz values were normalised across speakers to reduce the effects of anatomical and gender differences on formants (see online supplementary material for a full explanation of the normalisation procedure).

The labiograms of the seven vowels uttered in isolation are shown in Figure 13. Furthermore, Figure 14 shows midsagittal tongue contours from ultrasound imaging extracted from around the mid-point of the sustained tokens of each vowel (the front of the oral cavity is on the right side). In this figure, the tongue contours have been smoothed using a generalised additive model (Hastie \& Tibshirani 1986; Wood 2006) with polar

\footnotetext{
${ }^{3}$ We chose to use $\langle a\rangle$ and $\langle y\rangle$ over $\langle\mathrm{e}\rangle$ and $\langle\grave{y}\rangle$ for typographical simplicity.
} 


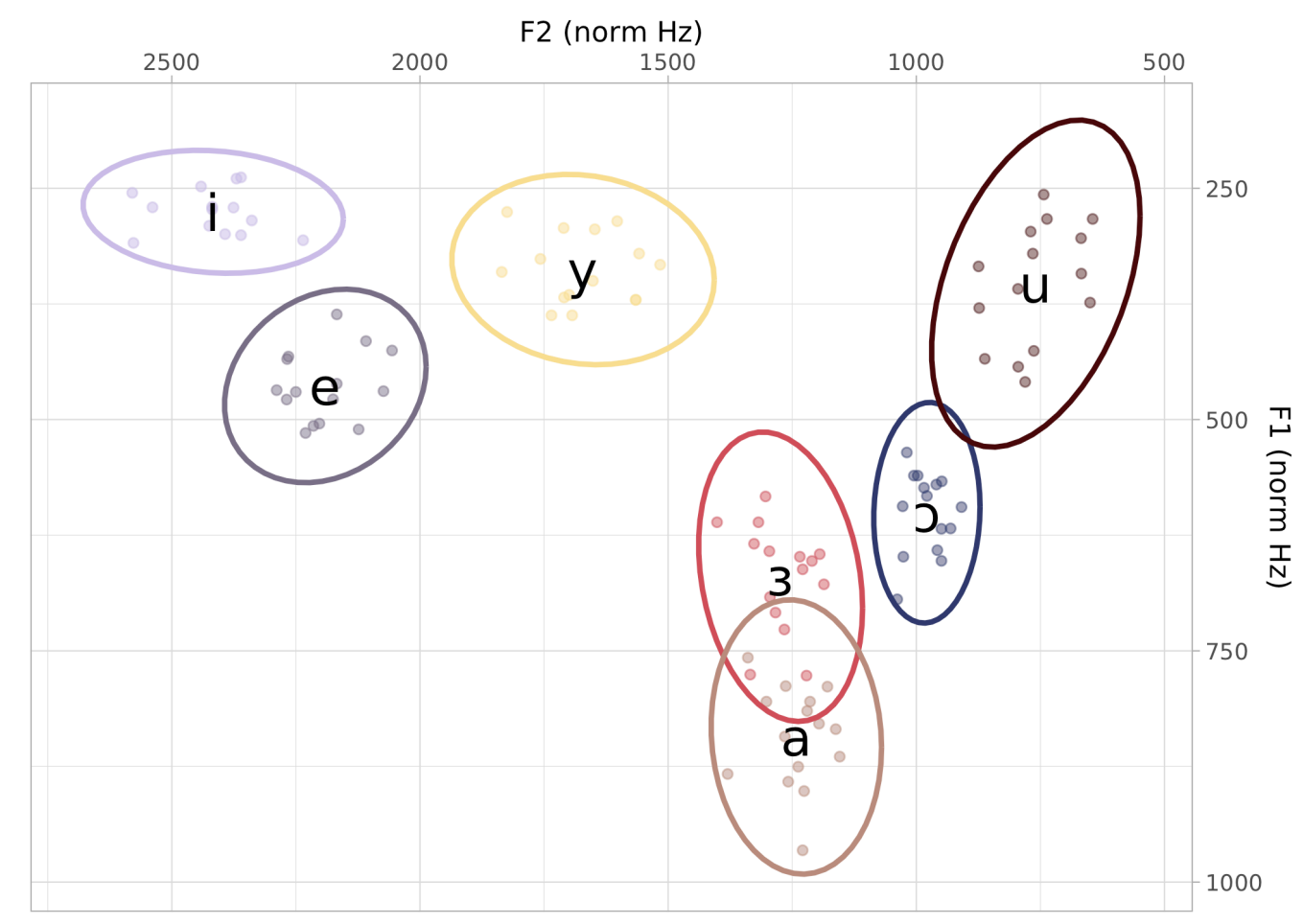

Figure 12: F1 and F2 space in normalised Hertz of the Albanian vowels, with $95 \%$ confidence ellipses and vowel labels at the centroids. See supplementary materials for a description of the normalisation procedure.

coordinates (Coretta 2019).

Note that the description to follow is restricted to data from lexicallystressed vowels. The characteristics of unstressed vowels may differ (cf. Belluscio 2014), although we did not investigate this thoroughly and leave it to future work. ${ }^{4}$

CLOSE VOWELS Among the close vowels, / $\mathrm{i} /$ is articulated as an unrounded, close and front [i]. It is tense; this is reflected in the peripheral position of /i/ in the acoustic F1/F2 space in Figure 12 and the position of

\footnotetext{
${ }^{4}$ Albanian also has various vowel sequences, although their phonological status is still a topic of debate and different authors propose different sets of diphthongal versus hiatus sequences (see for example Beci 2002). Targeted studies of the phonological and phonetic status of vowel sequences are needed to shed light on the matter but examples of certain sequences can be found in The North Wind and the Sun in Section 5 (e.g. in Dielli 'Sun').
} 


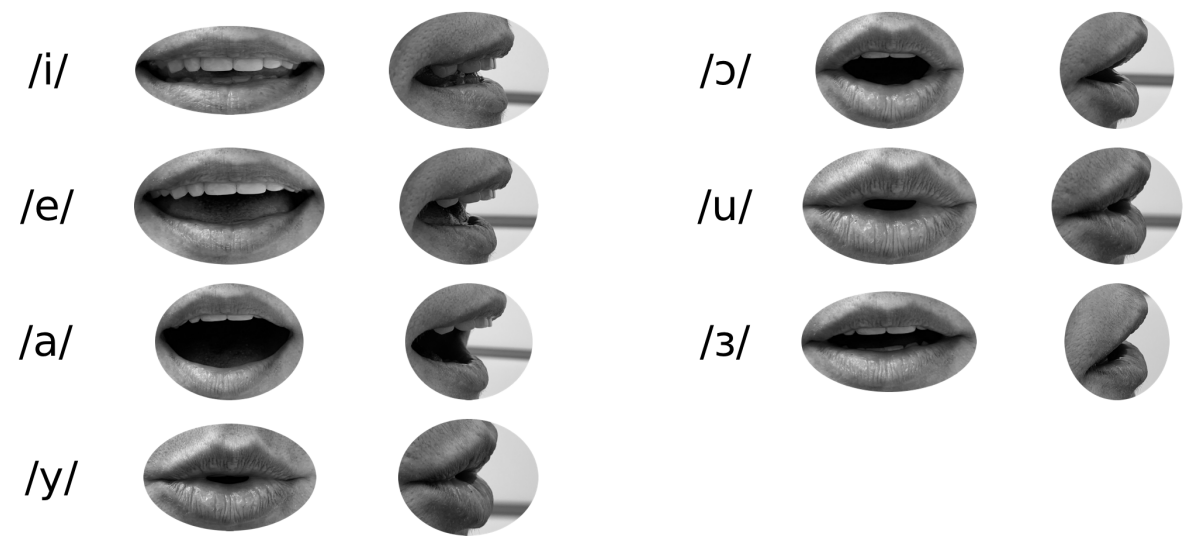

Figure 13: Labiograms of a sustained token of each vowel produced in isolation. A picture of the lips was taken first from the front then from the side.

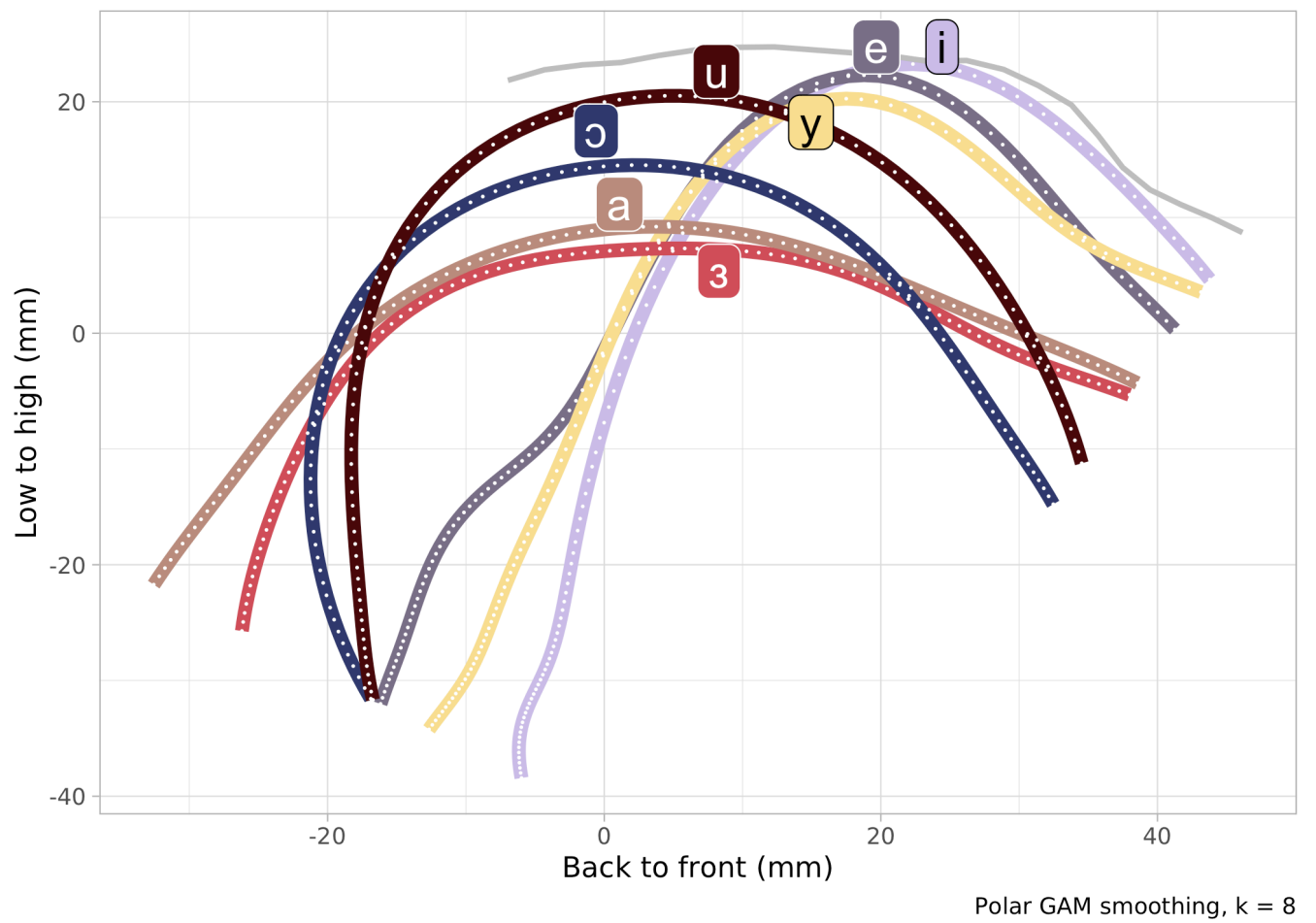

Figure 14: Smoothed midsagittal tongue contours from ultrasound tongue imaging, taken from the mid-point of sustained utterances of each vowels. The tongue tip is on the right and the tongue back on the left, the solid grey line indicates the surface of the hard palate. 
the tongue, which is markedly high and front, as evidenced in Figure 14. The vowel $/ \mathrm{y} /$ is a mid-centralised (i.e. lax) close front rounded vowel [Y]. The mid-centralised articulation of this vowel is clearly visible in Figure 14, which shows that the highest point of the midsagittal contour of the tongue in /y/ is lower than that of /i/ and /e/. In Figure 12, /y/also occupies a central position, although this could in part be attributable to both F3 and F2 having lower frequency in rounded vowels (Schwartz et al. 1993). The mid-centralised quality of / $y /$ was also observed by Newmark (1957) and Newmark et al. (1982). /u/ is a rounded close back vowel. Its quality ranges from close $[\mathrm{u}]$ to a more open [u] , as illustrated by its spread distribution in Figure 12. Figure 13 illustrates the very similar, if not identical, labial profiles of $/ \mathrm{y} /$ and $/ \mathrm{u} /$.

MID vowels Regarding the mid vowels, /e/ is front, close-mid and unrounded [e]. Figure 13 illustrates that /e/ is produced with lips as retracted as $/ \mathrm{i} /$ but with a greater degree of aperture. $/ \mathrm{J} /$ is a back, open-mid and rounded vowel [o]. Both the position of $/ \mathrm{J} /$ in the acoustic space and its tongue configuration show the open-mid nature of this vowel. $/ \mathrm{J} /$ is produced with rounded lips, though they are unsurprisingly not as protruted as for $/ \mathrm{y} /$ and $/ \mathrm{u} /$ due to the greater lip aperture.

The vowel written $\langle\ddot{e}\rangle$ in the Albanian writing system has traditionally been described as a mid central vowel (i.e. schwa). However, work on different varieties of Albanian by Granser \& Moosmüller (2002) shows that this vowel is characterised by a great deal of variation across speakers and contexts and that it deviates from the canonical mid central vowel [ə]. We identify this vowel as a central open-mid unrounded $/ 3 /$. In our data, $/ 3 /$ is more open than canonical [ə] and partially overlaps with $/ a /$ in the F1/F2 space. Interestingly, a similar kind of variation for this type of vowel has been reported for Nalögo, an Oceanic language of the Temotu (Alfarano 2021). Furthermore, the tongue contour in Figure 14 highlights the low position of the tongue in the articulation of $/ 3 /$, which is as low as that of $/ \mathrm{a} /$. What distinguishes these two vowels in terms of tongue configuration is in fact the tongue root, which is fronter for $/ 3 /$ than $/ a /$. 
Moreover, $/ 3 /$ shows some degree of lip protrusion, similar to that of $/ \mathrm{J} /$, while it is totally absent for $/ a /$. In sum, $/ 3 /$ is realised as a partially labialised open-mid central vowel [3̧ o o ].

OPEN VOWEL The only open vowel /a/ is articulated between an open central vowel [ä] and an open back vowel [a].

\section{Prosody}

As we are not aware of any study that has specifically addressed the stress and intonation system of Northern Tosk in particular, we will review here those that exist on Standard Albanian, given that Standard Albanian is based primarily on Northern Tosk (Kostallari 1984).

\subsection{Lexical stress}

Albanian is a stress-accent language (Hyman 2006), with traditional grammars referring to it as having "dynamic stress" (rather than "melodic stress", i.e. a pitch-accent system or lexical tones). More specifically, Çabej (1976), Demiraj (1984) and Topalli (1995), among others, argue that the primary acoustic correlates of stress are duration and intensity (although cf. Jubani-Bengu \& Conforti 2008 for a less robust role of intensity). The location of lexical stress has been argued to be predictable from either phonological or morphological structure (e.g. Demiraj 1984; Trommer \& Grimm 2004; Bermúdez-Otero 2011; Memushaj 2017). Generally speaking, primary lexical stress can be found on the final, penultimate and antepenultimate syllable of the word, as illustrated by the following words.

$\begin{array}{llll}\text { final } & \text { /li'ri/ } & \text { liri } & \text { 'freedom' } \\ \text { penultimate } & \text { /mu'l'1ri/ } & \text { mulliri } & \text { 'mill' } \\ \text { antepenultimate } & \text { /'flutura/ } & \text { flutura } & \text { 'butterfly' }\end{array}$


To assess which acoustic features might cue lexical stress in Northern Tosk, we extracted three measures from each vowel in the words liri /li.' $\mathrm{i}$ i/, mulliri /mu.'1'1 ${ }^{\mathrm{i}}$.ri/ and flutura /'flu.tu.ra/, as uttered by the five speakers in our corpus. From the total number of word tokens $(\mathrm{N}=45,3$ words times 3 repetitions times 5 speakers), we removed tokens that were uttered with a rising contour, which we attribute to the typical list effect when reading from a word list. Thirteen such word tokens were excluded from further analysis, leaving 32 tokens. From each vowel of these tokens we extracted vowel duration, maximum intensity and maximum f0, which we then z-scored to allow for cross-subject comparison. These are shown in Figure 15. Each dot represents a vowel and the grey lines link vowels belonging to the same word token. The stressed vowel in each token is marked by a red dot.

The top panel of Figure 15 shows measurements of vowel duration. The slope of each connecting grey line indicates whether duration increases (positive slope), decreases (negative slope) or does not change (horizontal line) when comparing one syllable to the next. For vowel duration, a general pattern emerges which indicates that stressed vowels tend to be longer than unstressed vowels. This is especially evident when comparing the antepenultimate and penultimate syllables in mulliri and flutura. Note that the increase of vowel duration in word-final position, albeit not universal, is a well-known phenomenon (White et al. 2020) and, as such, the increase observed in final syllables is not surprising.

The mid panel reports maximum intensity (i.e. peak intensity within each vowel). While there is a general tendency for stressed vowels to show higher intensity than unstressed vowels, the opposite pattern can also be observed in the data. Moreover, especially in flutura, some tokens are characterised by a stable maximum intensity value across two consecutive syllables. Finally, the maximum intensity values of the stressed vowels in mulliri and flutura show substantially less variation than those in the unstressed vowels. In sum, intensity might be playing a role as a cue to stress but less systematically so than vowel duration, which is also in line with Jubani-Bengu \& Conforti (2008). 

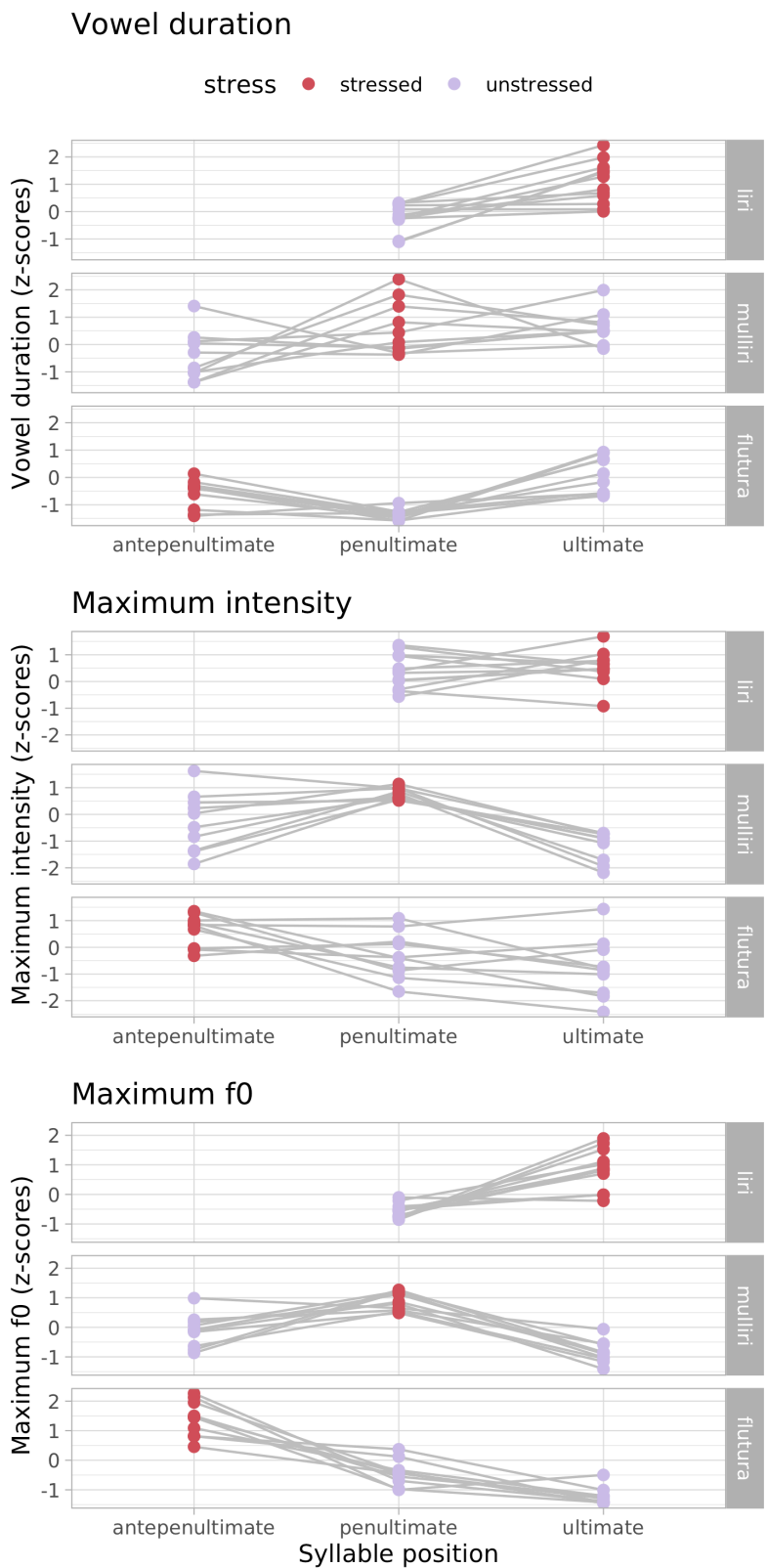

Figure 15: Three acoustic correlates of lexical stress: duration (top), intensity (middle) and f0 (bottom). Each dot represents a vowel and the grey lines link vowels belonging to the same token $(\mathrm{N}=32)$. Red dots represent stressed vowels. 
Maximum f0 is shown in the bottom panel of Figure 15. Fundamental frequency is systematically higher in stressed compared to unstressed vowels. This result is surprising in light of the traditional view that Albanian lexical stress is cued by duration and possibly intensity (Çabej 1976; Demiraj 1984; Topalli 1995; Jubani-Bengu \& Conforti 2008) but not by f0 (Jubani-Bengu \& Conforti 2008). However, f0 modulations are not unusual in stress-accent languages and the presence of durational, intensity and f0 differences in stressed vs unstressed vowels in production has been argued, for example, for Italian (Albano Leoni \& Maturi 1998; Alfano 2006; Alfano et al. 2009; Sulpizio \& McQueen 2012).

In sum, the data in our corpus suggest that vowel duration and fo can differentiate lexically-stressed from unstressed vowels (with the former being longer and having higher f0). While intensity might also play a role, we found less robust patterns for this cue than the other two.

\subsection{Intonation}

(a) Lena lau murin.

'Lena washed the wall.'

(b) Lena lau murin, jo lulen. 'Lena washed the wall, not the flowers.'

(c) A e lau Lena murin? 'Did Lena wash the wall?'

(d) Çfarë lau Lena? 'What did Lena wash?'

Figure 16 shows the f0 contours of a declarative sentence (a), a contrastive focus sentence (b), a polar question (c) and a content question (d) from three of our informants. Early descriptive studies have suggested that declarative sentences have a falling intonational contour, as seen in our corpus in sentences (a) and (b), while questions have a rising one, as in sentences (c) and (d) (Boriçi 1987; Memushaj 2015). More recent work has proposed that different informational-structure constructs, such as topic, informational focus and contrastive focus associate with different tunes in Standard Albanian (Kapia \& Brugos 2016, 2019; Kapia et al. 2020, forthcoming). The narrow focus pattern can be seen in the word murin in the polar question (c). 
Smoothed f0 contours

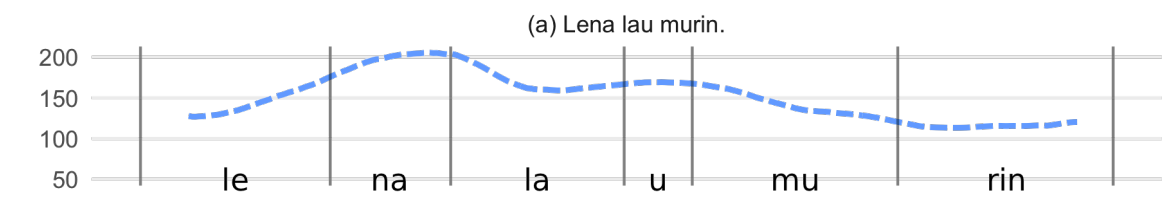

(b) Lena lau murin, jo lulen.

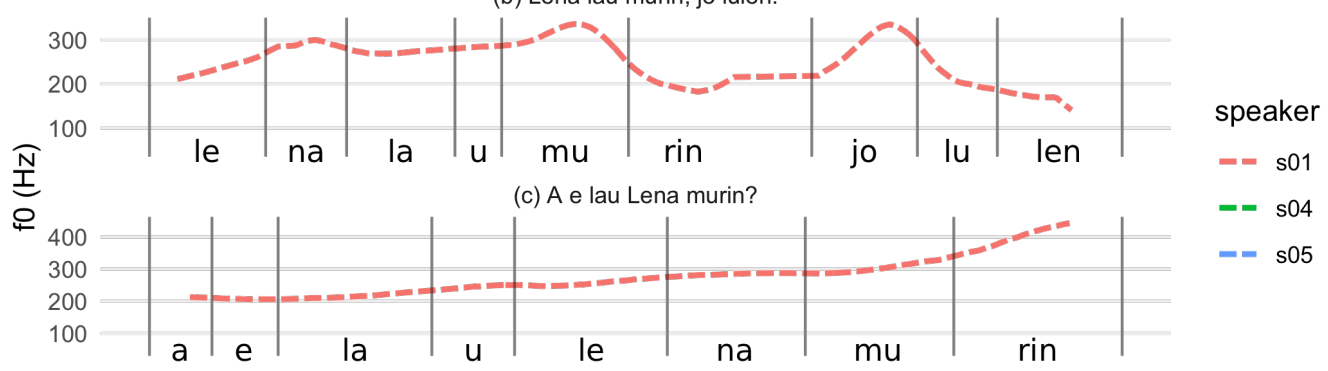

(d) Çfarë lau Lena?

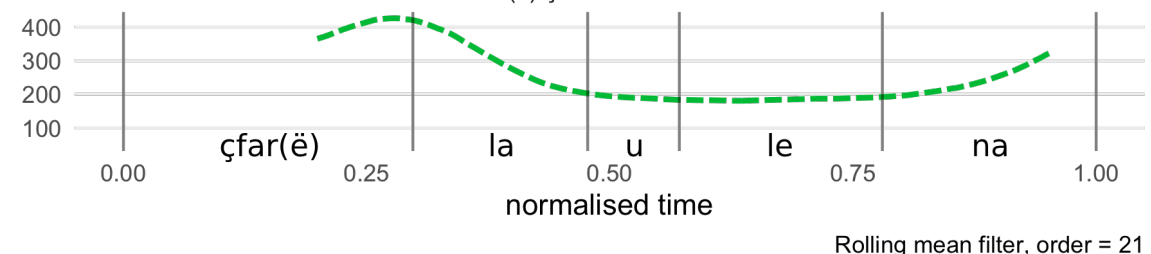

Figure 16: Smoothed intonation contours (f0) of (a) declarative sentence, (b) contrastive focus, (c) polar question, (d) content question. Normalised times of syllabic boundaries are marked by vertical lines within each panel. 


\section{The North Wind and the Sun}

\subsection{Albanian}

Era e Veriut dhe Dielli po ziheshin se kush ishte më i fortë, kur aty kaloi një udhëtar që kishte veshur një pallto të ngrohtë. Ata ranë dakord që kush do ta bënte udhëtarin të hiqte pallton më përpara do të quhej më i forti. Fill pas kësaj, Era e Veriut filloi të frynte me gjithë fuqinë e saj, por sa më shumë që frynte aq më shumë kapej udhëtari pas palltos së tij, derisa më në fund Era e Veriut u dorëzua. Pastaj Dielli lëshoi rrezet e tij të ngrohta dhe menjëherë udhëtari e hoqi pallton. E kështu Era e Veriut u detyrua të pranonte që dielli ishte më i fortë se ajo.

\subsection{Glossed phonemic transcription}

(1) Era e Veriut dhe Dielli po ziheshin se kush ishte më i fortë.

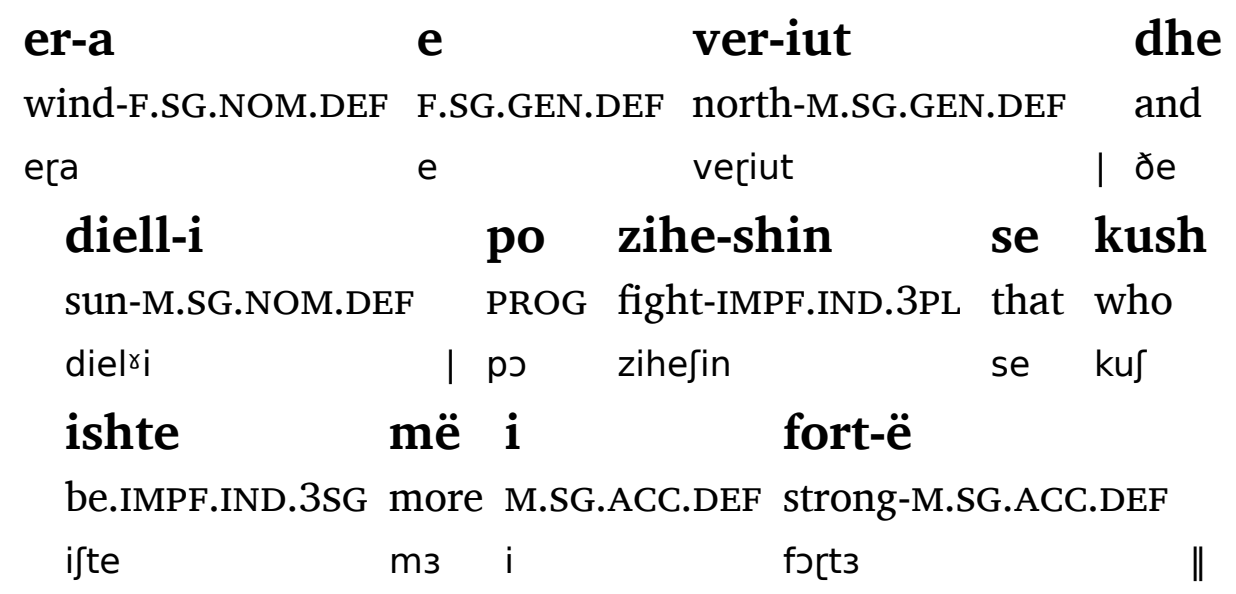

'The North Wind and the Sun were disputing which was the stronger,' 
(2) Kur aty kaloi një udhëtar që kishte vesh-ur një pallto të ngroht-ë.

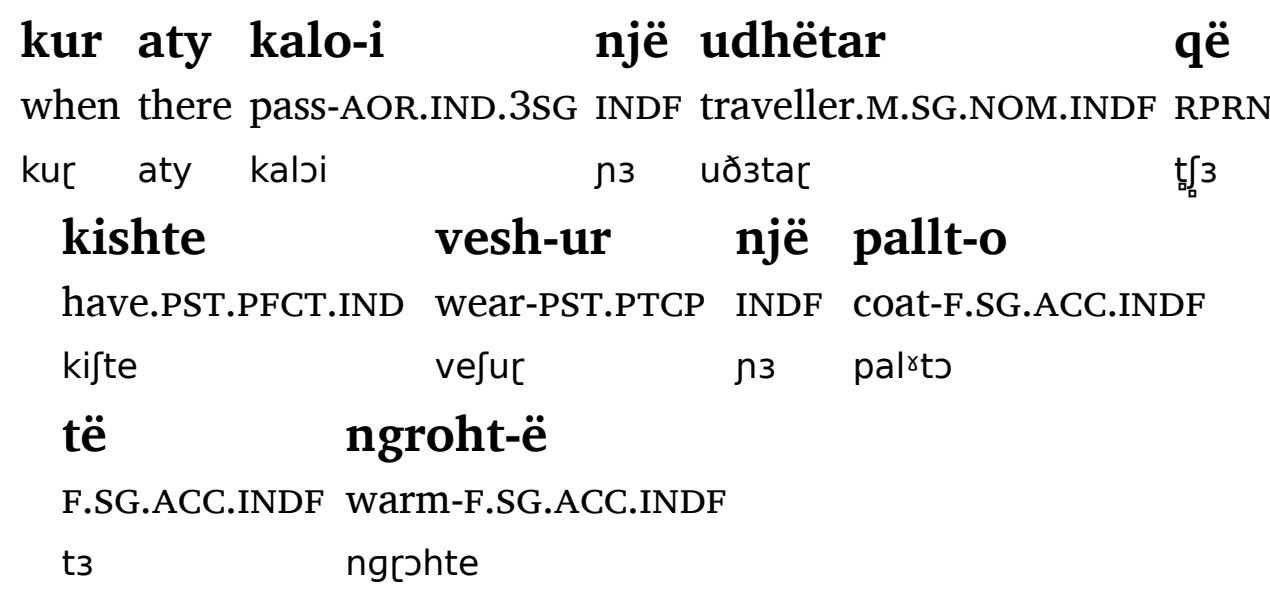

'when a traveller came along wrapped in a warm cloak.' 
(3) Ata ranë dakord që kush do ta bënte udhëtarin të hiqte pallton më përpara do të quhej më i forti.

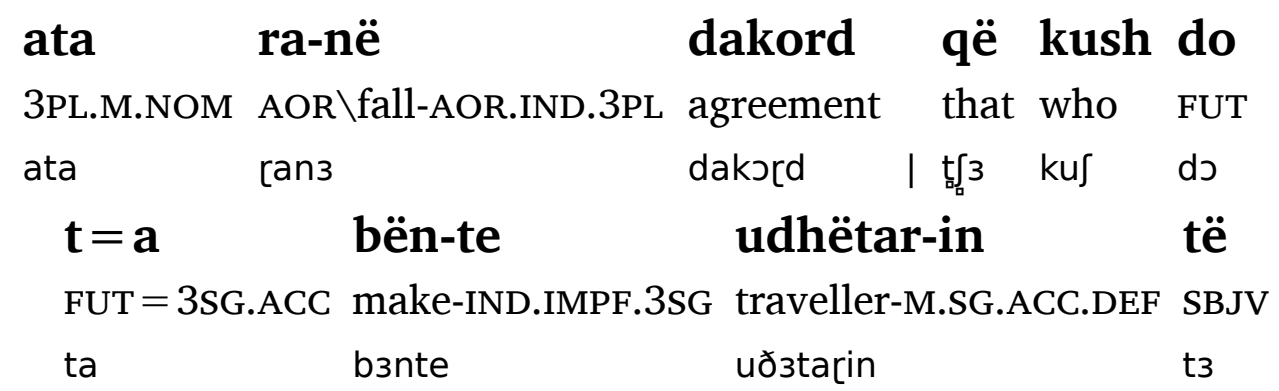

hiq-te pallt-on më përpara

SBJV \take_off-PST.SBJV.3SG coat-F.SG.ACC.DEF more soon

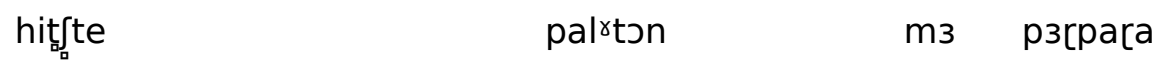

do të quh-ej më i

FUT FUT PASS $\backslash$ call-IMPF.IND.3SG more M.SG.NOM.DEF

do t3 tsuhej m3 i

\section{fort-i}

strong-M.SG.NOM.DEF

forti

$\|$

'They agreed that the one who first succeeded in making the traveller take his cloak off first should be considered the stronger one.' 
(4) Fill pas kësaj, Era e Veriut filloi të fry-nte me gjithë fuqinë e saj,

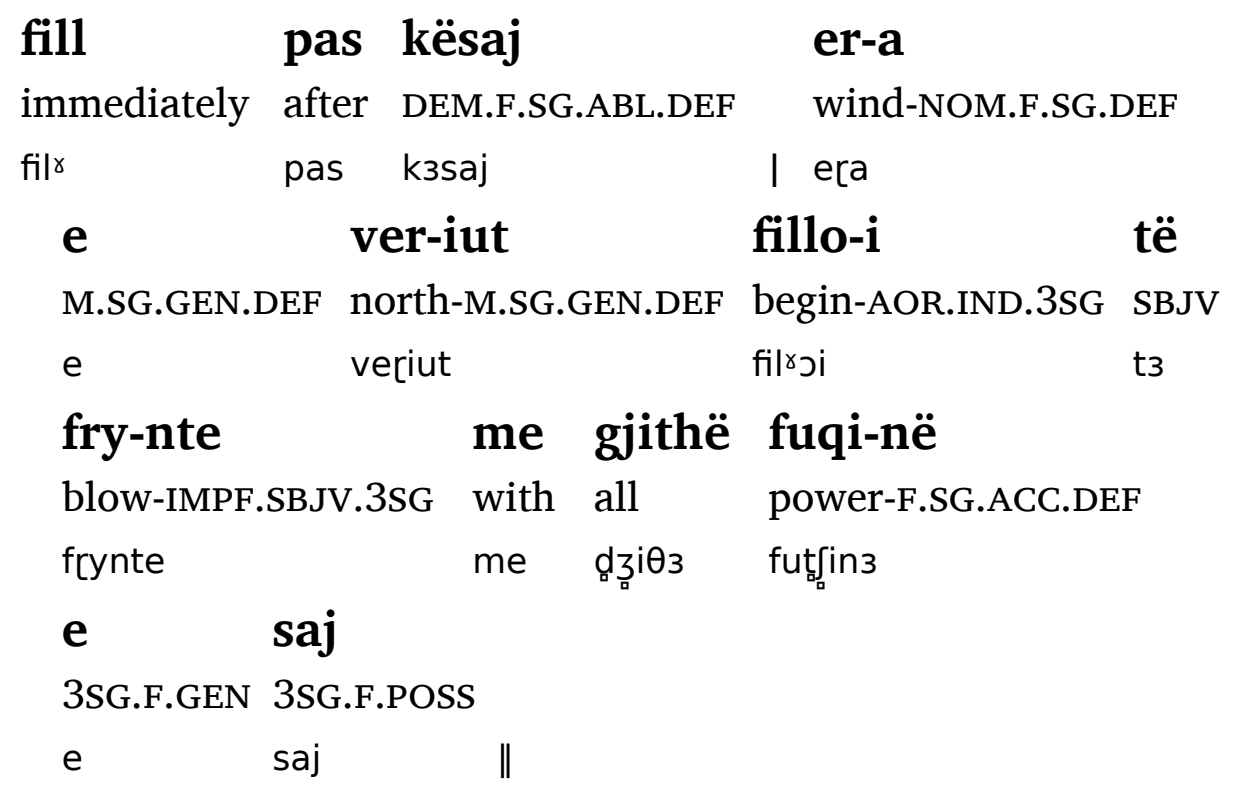

'Then the North Wind blew as hard as he could,'

(5) por sa më shumë që frynte aq më shumë kapej udhëtari pas palltos së tij,

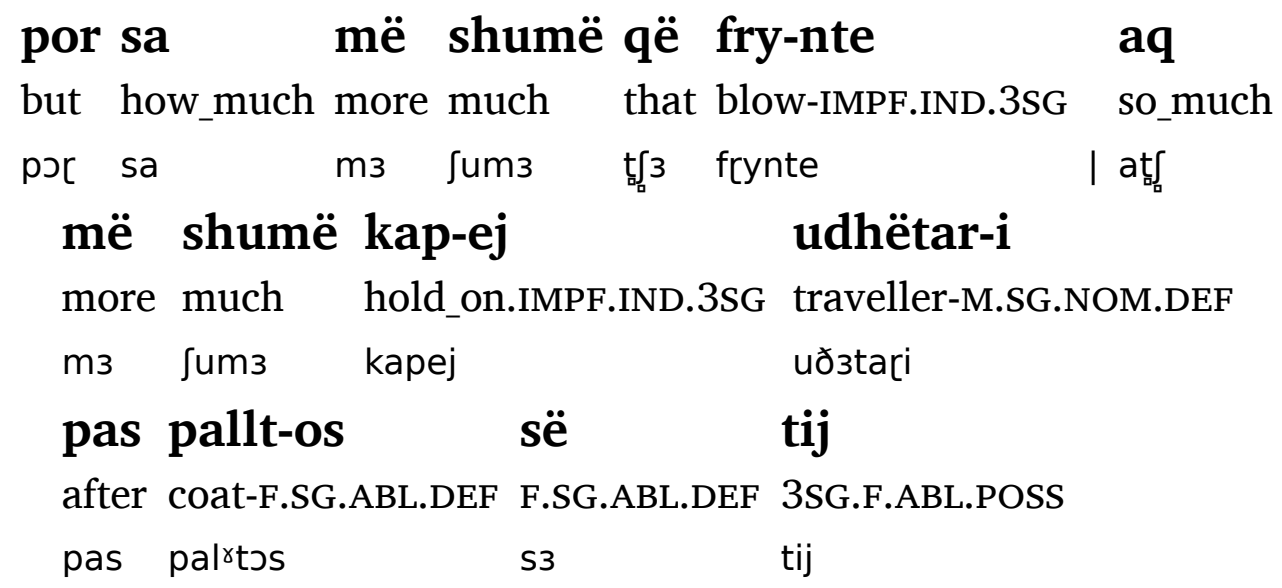

'but the more he blew the more closely did the traveller fold his cloak around him,' 
(6) derisa më në fund Era e Veriut u dorëzua.

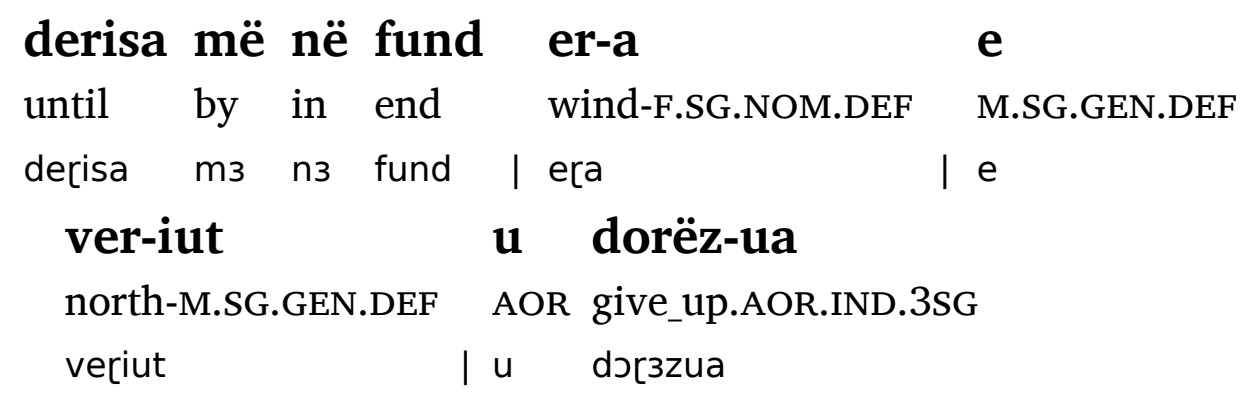

'and at last the North Wind gave up the attempt.'

(7) Pastaj Dielli lëshoi rrezet e tij të ngrohta dhe menjëherë udhëtari e hoqi pallton.

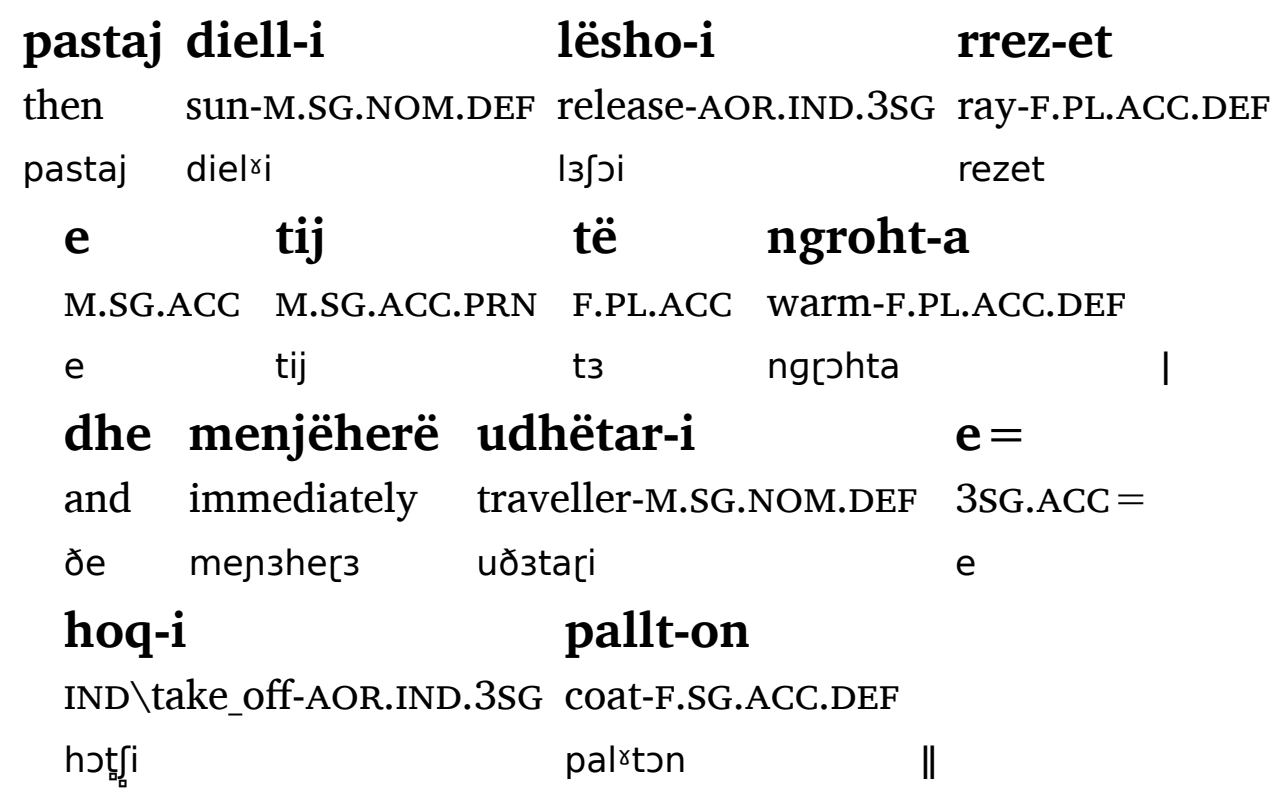

'Then the Sun released his warm rays and immediately the traveller took off his cloak.' 
(8) E kështu Era e Veriut u detyrua të pranonte që Dielli ishte më i fortë se ajo.

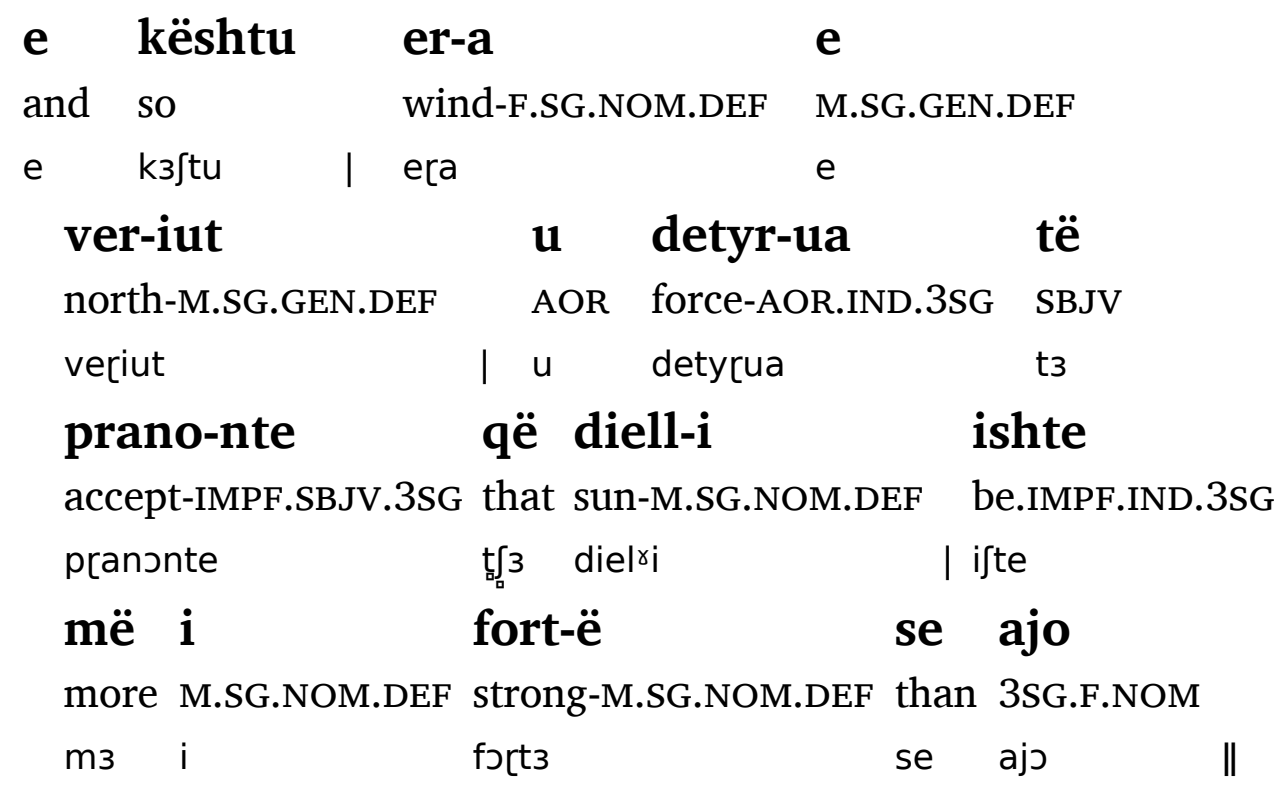

'And so the North Wind was forced to accept that the Sun was the stronger than itself.'

\subsubsection{Abbreviations}

$3=$ third person, $\mathrm{ABL}=$ ablative, $\mathrm{ACC}=$ accusative, $\mathrm{AOR}=$ aorist, $\mathrm{DEF}=$ definite, $\quad \mathrm{DEM}=$ demonstrative, $\mathrm{F}=$ feminine, $\mathrm{FUT}=$ future, $\mathrm{GEN}=$ genitive, $\mathrm{IMPF}=$ imperfect,$\quad \mathrm{IND}=$ indicative,$\quad \mathrm{INDF}=$ indefinite, $\mathrm{M}=$ masculine, $\mathrm{NOM}=$ nominative, $\mathrm{PASS}=$ passive, $\mathrm{PFCT}=$ perfect, $\mathrm{PL}=$ plural, POSS $=$ possessive, $\mathrm{PRN}=$ pronoun, $\mathrm{PROG}=$ progressive, $\mathrm{PST}=$ past, $\mathrm{PTCP}=$ participle, $\mathrm{RPRN}=$ relative pronoun, $\mathrm{SBJV}=$ subjunctive, $\mathrm{SG}=$ singular.

\subsection{Narrow phonetic transcription}

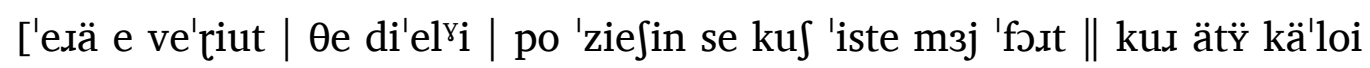

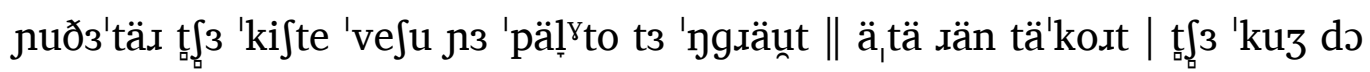




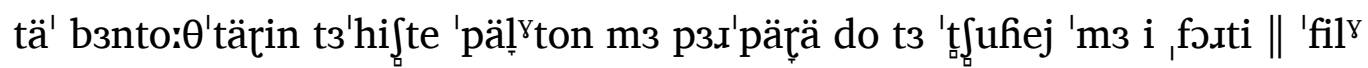

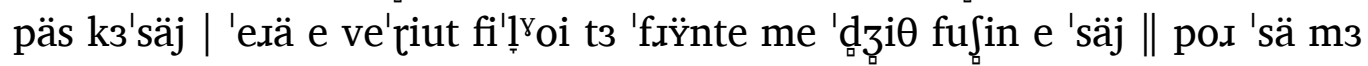

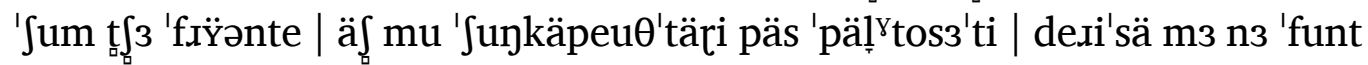

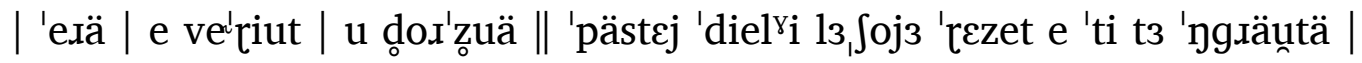
ðع mins'

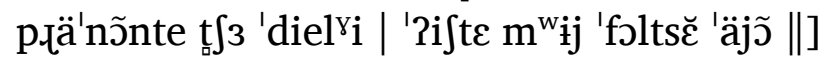

\section{Open Science statement}

The research compendium containing data and code used in this illustration can be found at https://osf.io/vry3h/ (Coretta et al. 2021).

\section{Authors' roles}

We follow the CRediT (Contributor Roles Taxonomy) standard in providing information about the roles and contribution of each author. A visual representation of the authors' roles is available here: https://github. com/stefanocoretta/alb-ipa/blob/main/img/credit-taxonomy.png. A description of the roles can be found here: http://credit.niso.org/ contributor-roles-defined/.

\section{Acknowledgements}

We would like to thank our consultant speakers who enthusiastically participated in this study. This study was supported by the European Research Council Grant No. 742289 Human interaction and the evolution of spoken accent (2017-2022) awarded to Prof. Jonathan Harrington (authors SC, EK), by the Georg Forster Fellowship of the Alexander von Humboldt Foundation (EK), by the Fonds de recherche du Québec - Société et Culture (JRC).

TBA. 


\section{References}

Albano Leoni, F. \& P. Maturi. 1998. Manuale di fonetica. Roma: Carocci.

Alfano, I. 2006. La percezione dell'accento lessicale: Un test sull'italiano a confronto con lo spagnolo. In C. Savy, R. \& Crocco (ed.), Atti del ii convegno nazionale dell'associazione italiana di scienze della voce, 632656.

Alfano, I., Savy, R. \& J. Llisterri. 2009. Sulla realtà acustica dell'accento lessicale in italiano ed in spagnolo: La durata vocalica in produzione e percezione. In L. Romito, V. Galatà \& R. Lio (eds.), Atti del iv convegno nazionale dell'associazione italiana di scienze della voce, 22-39.

Alfarano, Valentina. 2021. A grammar of Nalögo, an Oceanic language of Santa Cruz Island: Institut National des Langues et Civilisations Orientales (LACITO), Paris dissertation.

Antoniou, Mark, Catherine T. Best, Michael D. Tyler \& Christian Kroos. 2010. Language context elicits native-like stop voicing in early bilinguals' productions in both L1 and L2. Journal of Phonetics 38(4). 640653. doi:10.1016/j.wocn.2010.09.005.

Baranowski, Maciej \& Danielle Turton. 2015. Manchester English. In Raymond Hickey (ed.), Researching Northern English, 293-316. Amsterdam: John Benjamins.

Beci, Bahri. 1995. Të folmet veriperëndimore të shqipes dhe sistemi fonetik $i$ të folmes së Shkodrës. Tiranë: Mihal Duri.

Beci, Bahri. 2002. Dialektet e shqipes dhe historia e formimit të tyre: Autoktonia e shqiptarëve në dritën e të dhënave të dialektologiiisë historike shqiptare. Tiranë: Dituria.

Beci, Bahri. 2004. Fonetika e gjuhës shqipe. Tiranë: EDFA. 
Belluscio, Giovanni. 2014. Fonematica contrastiva albanese-italiano. In Gesuato S. \& Busà M.G (eds.), Festschrift in onore di Alberto Mioni, 277292. Padova: CLEUP.

Belluscio, Giovanni. 2016. Varietete/variante fonetike "tendenciale" në përdorimin e kontrolluar të shqipes standarde në një emision televiziv të sotëm. In Aktet e Seminarit XXXVI ndërkombëtar për gjuhën, letërsinë dhe kulturën shqiptare, 403-426.

Berez-Kroeker, Andrea L., Lauren Gawne, Susan Smythe Kung, Barbara F. Kelly, Tyler Heston, Gary Holton, Peter Pulsifer, David I. Beaver, Shobhana Chelliah \& Stanley Dubinsky. 2018. Reproducible research in linguistics: a position statement on data citation and attribution in our field. Linguistics 56(1). 1-18. doi:10.1515/ling-2017-0032.

Bermúdez-Otero, Ricardo. 2011. Cyclicity. In Marc van Oostendorp, Colin J. Ewen, Elizabeth Hume \& Keren Rice (eds.), The blackwell companion to phonology, 2019-48. Oxford: Wiley-Blackwell.

Bevington, Gary Loyd. 1971. Albanian phonology: University of Massachusetts Amherst dissertation.

Bopp, Franz. 1855. Über das Albanesische in seinen verwandtschaftlichen Beziehungen. Berlin: Dümmler.

Boriçi, L. 1987. Intonacioni dhe funksionet e tij në gjuhën shqipe. Studime Filologike 2. 74-87.

Çabej, Eqrem. 1975. Problemi $i$ vendit të formimit të gjuhës shqipe, vol. V. Prishtinë: Rilindja.

Çabej, Eqrem. 1976. Studime etimologiike në fushë të shqipes, vol. 2. Tiranë: Akademia e Shkencave e Shqipërisë.

Coretta, Stefano. 2019. Assessing mid-saggital tongue contours in polar coordinates using generalised additive (mixed) models. OSF pre-print. doi:10.31219/osf.io/q6vzb. 
Coretta, Stefano, Josiane Riverin-Coutlée, Enkeleida Kapia \& Stephen Nichols. 2021. IPA Illustration of Northern Tosk Albanian [tosk1239], (Research compendium). OSF. doi:10.17605/OSF.IO/VRY3H.

Crüwell, Sophia, Johnny van Doorn, Alexander Etz, Matthew C. Makel, Hannah Moshontz, Jesse Niebaum, Amy Orben, Sam Parsons \& Michael Schulte-Mecklenbeck. 2019. 7 easy steps to open science: an annotated reading list. Zeitschrift für Psychologie 227(4). 237-248. doi:10.1027/ 2151-2604/a000387.

Cysouw, Michael \& Jeff Good. 2013. Languoid, doculect, and glossonym: Formalizing the notion 'language'. Language Documentation \& Conservation 7. 331-359.

Demiraj, Shaban. 1984. Theksi në gjuhën shqipe. Studime Filologjike 2.

Demiraj, Shaban. 1986. Gramatikëhistorike e giuhës shqipe. Tiranë: Akademia e Shkencave e Shqipërisë.

Desnickaja, Agnija Vasiljevna. 1976. Çështje të dialektologjisë historike të gjuhës shqipe. Jehona 4. 305-310.

Dodi, Alastas. 2004. Fonetika dhe fonologiia e gjuhës shqipe. Akademia e Shkencave e Shqipërisë.

Dodi, Anastas. 1996. Kundërvëniet fonologjike të bashkëtingëlloreve të shqipes letrare mbi bazën e tipareve akustike. Studime Filologiike 1-4.

Elsie, Robert \& Josef Gross. 2009. Albanian dialects. http://dialects. albanianlanguage. net.

Gjinari, Jorgji. 1985. Marrëdhëniet e sotme tëgjuhës letrare me dialektet. Studime Filologiike 22(1). 43-52.

Gjinari, Jorgji. 1988. Dialektologjia shqiptare. Tiranë: Akademia e Shkencave të Shqipërisë. 
Gjinari, Jorgji, Bahri Beci, Gjovalin Shkurtaj, Xheladin Gosturani \& Anastas Dodi. 2007. Atlasi dialektologjik i gjuhës shqipe. Napoli: Università degli Studi di Napoli.

Granser, Theodor \& Sylvia Moosmüller. 2002. Phonemic schwa - a challenge for Natural Phonology? the case of Albanian. In Katarzyna Dziubalska-Kołaczyk \& Jarosław Weckwerth (eds.), Future challenges for natural linguistics, 165-178. München: Lincom.

von Hahn, Johann Georgw. 1853. Albanesiche Studien. Wien: Friedrich Mauke.

Hastie, Trevor \& Robert Tibshirani. 1986. Generalized additive models. Statistical Science 1(3). 297-310. doi:10.1201/9780203753781-6.

Hetzer, Armin. 1995. Nominalisierung und verbale Einbettung in Varietäten des albanischen: eine untersuchung zur geschichte der albanischen schriftsprache am beispiel erweiterter Verbalprädikate auf areallinguistischem Hintergrund, vol. 28. Wiesbaden: Harrassowitz.

Hyman, Larry. 2006. Word-prosodic typology. Phonology 23. 225-257. doi:10.1017/S0952675706000893.

Hysenaj, Haki. 2009. Kundërvënia fonologjike /r/-/R/, rrafshim dhe reflekse në gjuhën e folur dhe të shkruar. In Aktet e seminarit xxviii ndërkombëtar për gjuhën, letërsinë dhe kulturën shqiptare, 403-408.

International Phonetic Association. 1999. Handbook of the international phonetic association: a guide to the use of the international phonetic alphabet. Cambridge: Cambridge University Press.

Jubani-Bengu, Aljula. 2011. Karakterizimi funksional i sistemit bashkëtingëllor të shqipes standarde. Buletini i Universitetit Planetar të Tiranës

Jubani-Bengu, Aljula. 2012. Fonetikë akustike. analizë e sistemit fonologjik. Tiranë: SHPSH. 
Jubani-Bengu, Aljula \& Emilia Conforti. 2008. I parametri acustici dell'accento nella parlata di San Benedetto Ullano e nell'albanese standard. In Quaderni del dipartimento di linguistica, vol. 18, Università di Firenze.

Kapia, Enkeleida \& Alejna Brugos. 2016. Information structure-prosody interface: Towards a model of Albanian intonational phonology. In Proceedings of the 6th international conference on speech prosody 2016, 946-950.

Kapia, Enkeleida \& Alejna Brugos. 2019. Perception of prosodic correlates of topic and focus in Albanian. ICPhS Satellite Workshop: Intonational Phonology of Typologically Rare or Understudied Languages.

Kapia, Enkeleida, Jonathan Harrington \& Felicitas Kleber. forthcoming. An autosegmental-metrical analysis of Albanian prosody. In S. A. Jun \& S. Dowla Khan (eds.), Prosodic typology, vol. III, Oxford University Press.

Kapia, Enkeleida, Felicitas Kleber \& Jonathan Harrington. 2020. An autosegmental-metrical analysis of rising contours in Standard Albanian. In Proceedings of the 10th international conference on speech prosody $2020,171-175$.

Klein, Jared, Joseph Brian \& Matthias Fritz. 2018. Handbook of Comparative and Historical Indo-European Linguistics. Walter de Gruyter.

Kolgjini, Julie M. 2004. Palatalization in Albanian: An acoustic investigation of stops and affricates: University of Texas at Arlington dissertation.

Kostallari, Androkli. 1984. Gjuha e sotme kombëtare shqipe dhe epoka jonë. Studime Filologiike 21(4). 25-59.

Ladefoged, Peter. 2003. Phonetic data analysis. Blackwell Publishing.

Ladefoged, Peter \& Ian Maddieson. 1996. The sounds of the world's languages. Oxford: Blackwell. 
Lowman, Guy Sumner. 1932. The phonetics of Albanian. Language 8(4). 271-293. doi:10.2307/408833.

Maniwa, Kazumi, Allard Jongman \& Travis Wade. 2009. Acoustic characteristics of clearly spoken English fricatives. The Journal of the Acoustical Society of America 125(6). 3962-3973.

Memushaj, Rami. 2005. Tiparet binare të fonemave të shqipes standarde. Studime Filologiike 43(3-4). 41-64.

Memushaj, Rami. 2011. Fonetikë e shqipes standarde. Tiranë: Shtëpia Botuese Toena.

Memushaj, Rami. 2015. Fonetika e shqipes standarde. Tiranë: Infbotues.

Memushaj, Rami. 2017. Studime gjuhësore. Tiranë: Botimpex.

Newmark, Leonard. 1957. Structural grammar of Albanian (indiana university research center in anthropology,folklore, and linguistics. publication 4), vol. 8. Bloomington: Indiana University.

Newmark, Leonard, Philip Hubbard \& Peter R Prifti. 1982. Standard Albanian: A reference grammar for students. Stanford, CA: Stanford University Press.

Pedersen, Holger. 1897. Die albanesichen 1-laute. KZ 33. 535-551.

Rusakov, Alexander. 2017. Albanian. In Mate Kapović (ed.), The IndoEuropean languages, Routledge.

Schwartz, Jean-Luc, Denis Beautemps, Christian Abry \& Pierre Escudier. 1993. Inter-individual and cross-linguistic strategies for the production of the [i] vs. [y] contrast. Journal of Phonetics 21(4). 411-425.

Shkurtaj, Gjovalin. 1975. E folmja e Kelmendit. In Mahir Domi (ed.), Dialektologjia Shqiptare, vol. III, 5-130. Tiranë: Akademia e Shkencave e Shqipërisë. 
Shkurtaj, Gjovalin. 2012. Dialekte e shqipes: Tiparet e përbashkëta dhe dallimet dialektore sipas hartave të adgjsh-së. Të folmet shqipe të diasporës. Tiranë: Morava.

Sulpizio, Simone \& James M. McQueen. 2012. Italians use abstract knowledge about lexical stress during spoken-word recognition. Journal of Memory and Language 66(1). 177-193. doi:https://doi.org/10.1016/j. jml.2011.08.001.

Topalli, Kolec. 1995. Theksi në giuhën shqipe. Shtëpia Botuese Enciklopedike.

Trommer, Jochen \& Angela Grimm. 2004. Albanian word stress. https: //home.uni-leipzig.de/jtrommer/papers/alb.pdf.

White, Laurence, Silvia Benavides-Varela \& Katalin Mády. 2020. Are initial-consonant lengthening and final-vowel lengthening both universal word segmentation cues? Journal of Phonetics 81. 100982. doi: https://doi.org/10.1016/j.wocn.2020.100982.

Wood, Simon. 2006. Generalized additive models: an introduction with $R$. Boca Raton: CRC Press. 